\title{
Theoretical Investigation of the Reaction Mechanism of the Hydrodeoxygenation of Guaiacol over a Ru (0001) Model Surface
}

\author{
Jianmin Lu and Andreas Heyden* \\ Department of Chemical Engineering, University of South Carolina, 301 S. Main St., \\ Columbia, South Carolina 29208, USA
}

*Corresponding author. Telephone: +1 8037775025; Fax: +1 8037770973.

E-mail address: heyden@ cec.sc.edu (A. Heyden). 


\begin{abstract}
The reaction mechanism of the hydrodeoxygenation of guaiacol to aromatic products has been studied by density functional theory calculations and microkinetic modeling over a $\mathrm{Ru}$ (0001) model surface. Our model suggests that the dominant hydrodeoxygenation pathway proceeds via $\mathrm{O}-\mathrm{H}$ bond cleavage of guaiacol, $\mathrm{C}_{6} \mathrm{H}_{4}(\mathrm{OH})\left(\mathrm{OCH}_{3}\right)$, to $\mathrm{C}_{6} \mathrm{H}_{4}(\mathrm{O})\left(\mathrm{OCH}_{3}\right)$, followed by dehydrogenation of the methoxy group to $\mathrm{C}_{6} \mathrm{H}_{4}(\mathrm{O})(\mathrm{OC})$, decarbonylation to $\mathrm{C}_{6} \mathrm{H}_{4} \mathrm{O}$, and finally hydrogenation to phenol. At the adsorbed $\mathrm{C}_{6} \mathrm{H}_{4}(\mathrm{O})(\mathrm{OCH})$ intermediate, a competitive deoxygenation pathway is identified that involves methyne group removal to $\mathrm{C}_{6} \mathrm{H}_{4} \mathrm{O}_{2}$, followed by hydrogenation to $\mathrm{C}_{6} \mathrm{H}_{4}(\mathrm{OH})(\mathrm{O})$, dehydroxylation to $\mathrm{C}_{6} \mathrm{H}_{4} \mathrm{O}$ and finally hydrogenation to phenol. In agreement with experimental results, phenol is predicted to be the major product and catechol is the most relevant minority side product. Further deoxygenation of phenol to benzene is found to be slow. Finally, computations predict the last dehydrogenation step of the methoxy species in guaiacol to be at least partially rate controlling over $\mathrm{Ru}(0001)$.
\end{abstract}

Keywords: guaiacol; ruthenium; density functional theory; microkinetic modeling; deoxygenation; hydrodeoxygenation; lignin 


\section{Introduction}

With the continued depletion of fossil resources as a source for fuels and chemicals, renewable raw materials such as biomass have drawn more and more attention as a possible source for fuels and chemicals. Bio-oils produced from fast pyrolysis and hydrothermal liquefaction of lignocellulosic biomass have been identified as a promising alternative feedstock for fuels and chemical production with several environmental advantages. For example, bio-oil production is $\mathrm{CO}_{2}$ neutral and its conversion emits no $\mathrm{SO}_{x}$ and $50 \%$ less of $\mathrm{NO}_{x}$ than diesel oil combustion in a gas turbine.[1] The composition of bio-oils depends heavily on the type of biomass and the production conditions, but bio-oils are generally a complex mixture of water (15-30\%) and many organic compounds, including organic acids, aldehydes, alcohols, esters, phenol derivatives (50-65\%) and lignin-derived oligomers (20\%).[2, 3] A disadvantage of biooils is their high viscosity, high corrosiveness (acidity), instability and low heating value etc. originating from the high oxygen content of most bio-oils. Therefore, upgrading of bio-oils, i.e., deoxygenation, is critical for its application as a liquid fuel or chemical feedstock.

Catalytic upgrading of bio-oils is commonly done by hydrodeoxygenation (HDO), which involves the challenging $\mathrm{C}-\mathrm{O}$ bond cleavage reaction. Since bio-oils are a mixture of hundreds of compounds, the only viable strategy for better understanding the catalytic upgrading process involves the mechanistic investigation of model compounds. Guaiacol $\left(\mathrm{C}_{6} \mathrm{H}_{4}(\mathrm{OH})\left(\mathrm{OCH}_{3}\right)\right)$ is such a representative compound of phenol derivatives and ligninderived oligomers since it contains one phenyl ring and two oxygen-containing functional groups, $-\mathrm{OH}$ and $-\mathrm{OCH}_{3}$. A considerable number of papers have reported experimental 
investigations on the catalytic hydrodeoxygenation of guaiacol on transition metals such as $\mathrm{Fe}[4,5], \mathrm{Ru}[5-7], \mathrm{Rh}[7-9], \mathrm{Pd}[5,7,8], \mathrm{Pt}[5,7,8,10]$ and bimetallic catalysts such as Co-Mo[11], Pt-Sn[12], Ni-Cu[13], Rh-Pt[8] and Pd-Fe[5]. Nimmanwudipong and coworkers[10] have mapped a reaction network for the hydrodeoxygenation of guaiacol over $\mathrm{Pt} / \gamma-\mathrm{Al}_{2} \mathrm{O}_{3}$ in the presence of $\mathrm{H}_{2}$ based on selectivity-conversion data, which is very insightful but lacks straightforward evidence. Sun and co-workers[5] have also proposed on the basis of their products a possible reaction pathway for $\mathrm{Ru}, \mathrm{Pd}$, and Pt catalysts, guaiacol $\rightarrow$ catechol $\rightarrow$ phenol $\rightarrow$ benzene and a different one, guaiacol $\rightarrow$ phenol $\rightarrow$ benzene, for Fe and Pd-Fe catalysts.

In this study, we aim at identifying the reaction mechanism and possible activity descriptors for the HDO of guaiacol over Ru (0001) model surfaces using density functional theory calculations and mean-field microkinetic modeling. To the best of the authors' knowledge, no theoretical study on the catalytic hydrodeoxygenation of guaiacol over transition metal catalysts has yet been published.

\section{Methods}

All calculations presented in this work were performed using the periodic DFT implementation in the Vienna Ab Initio Simulation Package (VASP).[14, 15] The electron-ion interactions were described by the projector-augmented wave method (PAW). The PAW method is a frozen core all-electron method which uses the exact shape of the valence wave functions instead of pseudo-wave functions.[16] The exchange correlation energy has been calculated within the generalized gradient approximation (GGA) using the PBE functional form.[17, 18] For dispersion interactions 
we used the DFT-D3 methodology.[19] An energy cutoff for plane waves of $400 \mathrm{eV}$ was employed throughout this study.

The total energy of HCP-Ru bulk approaches a minimum when its lattice constants are $\mathrm{a}=2.7020 \AA$ and $\mathrm{c}=4.2741 \AA$, which is in reasonable agreement with the experimental values ( $a=2.7059 \AA$ and $c=4.2815 \AA[20])$. The $R u(0001)$ surface was constructed as a periodic slab with four Ru layers separated by a vacuum layer of $15 \AA$ in order to eliminate interactions between the slab and its images. Each Ru layer had $16 \mathrm{Pd}$ atoms with a $(4 \times 2 \sqrt{ } 3)$ periodicity, allowing for adsorbate coverages as low as 1/16 ML. The bottom two $\mathrm{Ru}$ layers were fixed to their optimized bulk configuration during all computations, while the top two layers were fully relaxed. The adsorbates were free to relax in all directions. All atomic coordinates of the adsorbates and the Ru atoms in the relaxed layers were optimized to a force less than $0.03 \mathrm{eV} / \AA ̊$ on each atom. All selfconsistent field (SCF) calculations were converged to $1 \times 10^{-3} \mathrm{~kJ} / \mathrm{mol}$. Brillouin zone integration was performed using a $4 \times 4 \times 1$ Monkhorst-Pack grid and a Methfessel-Paxton smearing of $0.2 \mathrm{eV}$. In all cases the convergence of total energy with respect to the kpoint mesh and with respect to plane-wave energy cutoff has been confirmed. The convergence criterion for the total energy was set to $10^{-7} \mathrm{eV}$.

Adsorption energies of all the surface intermediates reported in this paper were calculated in their most favorable adsorption modes. The adsorption energies, $E_{\text {ads, }}$, were calculated by the following equation

$$
E_{\text {ads }}=E_{\text {slab+adsorbate }}-E_{\text {slab }}-E_{\text {adsorbategas })}
$$


where $E_{\text {slab+adsorbate }}$ is the total energy of an adsorbate bound to the $\mathrm{Ru}$ slab, $E_{\text {slab }}$ is the total energy of the clean Ru slab, and $E_{\text {adsorbate(gas) }}$ is the total energy of the adsorbate in the gas phase.

Finally, transition states for elementary reaction steps were determined by a combination of the nudged elastic band (NEB) method[21] and the dimer method.[22-24] In the NEB method, the path between the reactant and product is discretized into a series of structural images. The image which is closest to a likely transition state structure was then employed as an initial guess structure for the dimer method. All adsorption energies and activation barriers reported in this study have been zero point corrected ( $\triangle \mathrm{ZPE})$.

For the microkinetic modeling, we have employed the same methodology as described in our previous paper.[25] The nonlinear steady state surface species equations have been solved using the BzzMath library[26] developed by G. Buzzi-Ferraris.

\section{Results and discussion}

Figure 1 illustrates the reaction pathways included for the HDO of guaiacol to benzene over the $\mathrm{Ru}(0001)$ surface model. In the following, we will first discuss the effects of dispersion corrections in section 3.1. Then, we report the adsorption behavior of reactants, products and surface intermediates in section 3.2. Finally, we will investigate each reaction pathway shown in Figure 1 individually in sections 3.3.

(Figure 1 here)

\subsection{Effects of dispersion corrections}


It is well known that conventional DFT fails to capture dispersion forces (van der Waals forces) which often dominate the interactions between alkanes and aromatics with transition metal surfaces.[27] For example, the adsorption energy of benzene on a $\mathrm{Ag}(111)$ surface has experimentally been determined to be $-0.69 \mathrm{eV},[28]$ while conventional DFT predicts a weak adsorption (-0.09 eV[29]) or even no adsorption.[19] DFT with dispersion corrections predicts adsorption energies closer to the experimental values $\left(-0.75 \mathrm{eV}^{[29]}\right.$ by $\mathrm{PBE}+\mathrm{vdW}^{\text {surf }}$ and $-0.95 \mathrm{eV}[19]$ by revPBE-D3). Table 1 illustrates a similar trend in adsorption energies of various reaction intermediates in the HDO of guaiacol over Ru (0001) computed with PBE-D3 and PBE functional. For aromatic surface intermediates, PBE-D3 predicts a 0.9 to $1.3 \mathrm{eV}$ stronger adsorption energy than PBE. It is noticeable that PBE-D3 also predicts a higher adsorption energy for the smaller surface species such as $\mathrm{H}, \mathrm{OH}, \mathrm{H}_{2} \mathrm{O}, \mathrm{CO}$ etc., which is likely an overestimation of the adsorption energy. For example, the $\mathrm{CO}$ adsorption energy has experimentally been estimated to be $-1.81 \mathrm{eV}$ on $\mathrm{Ru}(0001)$.[30] $\mathrm{PBE}$ slightly overestimates the adsorption energy by $0.05 \mathrm{eV}\left(\Delta \mathrm{E}_{0}=-1.86 \mathrm{eV}\right)$, while PBE-D3 significantly overestimates it by about $0.25 \mathrm{eV}\left(\Delta \mathrm{E}_{0}=-2.06 \mathrm{eV}\right)$. Fortunately, Table 2 illustrates that reaction energies for surface reactions are fairly independent of functional / dispersion interaction. For the test set of elementary surface reactions the difference in surface reaction energy between PBE and PBE-D3 is less than $0.1 \mathrm{eV}$. As a result, we conclude that PBE-D3 will likely provide a meaningful description of the surface chemistry of the HDO of guaiacol; although, predicted surface coverages of, e.g., $\mathrm{CO}$ and $\mathrm{H}$ will likely be overestimated, primarily due to the neglect of electronic screening at the metal surface.[31] 


\subsection{Adsorbed intermediates}

Adsorption geometries of the reactants, products and possible intermediates involved in the reaction network are shown in Figure 3 and 4. The number of adsorption sites, adsorption energies and zero point energy corrections of these intermediates are listed in Table 3 .

(Figure 2, 3 and 4 here)

For aromatic molecules, we generally find they can adsorb at four different adsorption sites (atop, bridge, fcc and hcp) on the $\mathrm{Ru}(0001)$ surface. As shown in Figure 3, all aromatic adsorbates bind to the $\mathrm{Ru}(0001)$ surface via their aromatic ring/carbon atoms, i.e., the aromatic rings are parallel to the $\mathrm{Ru}(0001)$ surface. In addition, they can adsorb in two orientations of $0^{\circ}$ and $30^{\circ}$ at each site, referring to the angles of the C-C bond relative to the close-packed $\mathrm{Ru}-\mathrm{Ru}$ bond as shown in Figure 2. Our calculations predict that all 26 aromatic surface intermediates adsorb preferentially in the hcp30 geometry (see Figure 3). For comparison, Liu et al. found that benzene prefers to chemisorb in bridge30 position on the (111) surfaces of Ir, Rh, Pd and Pt.[29] Finally, all aromatic reactants and products such as guaiacol, anisole, catechol, phenol and benzene adsorb strongly on the $\mathrm{Ru}(0001)$ surface with an adsorption energies of $\Delta \mathrm{E}_{0} \approx-2.5 \mathrm{eV}$.

\subsection{Potential energy surface of various reaction pathways}

Various reaction pathways investigated for the HDO of guaiacol are shown in Figure 1. Pathways leading to cyclic, saturated products such as cyclohexanone and cyclohexanol are not taken into consideration in this reaction network, primarily because 
these pathways are not favorable on $\mathrm{Ru}$ catalysts at low $\mathrm{H}_{2}$ partial pressure.[5] In the following, we labeled the reaction pathways (1 to 7) according to the first reaction step labeled step 1 to 7 in Figure 1. Pathway 1 and 2 start with hydrogenation steps of the $\beta$ carbon and $\alpha$ carbon of guaiacol, respectively. Pathways 3, 4, and 6 start with $-\mathrm{OH}$, $-\mathrm{CH}_{3}$, and $-\mathrm{OCH}_{3}$ removal from guaiacol, respectively. Finally, pathway 5 starts with dehydrogenation of the $-\mathrm{OCH}_{3}$ group of guaiacol and pathway 7 starts with dehydrogenation of the $-\mathrm{OH}$ group. All reaction energies and activation barriers for the elementary steps investigated are listed in Table 4. Snapshots for transition states of all elementary steps involved in the microkinetic modeling are shown in Figures 5 and 6.

\subsubsection{Pathways involving partial hydrogenations of the phenyl ring}

In pathway 1 , adsorbed guaiacol is hydrogenated on the $\beta$ carbon of the phenyl ring to form $\mathrm{C}_{6} \mathrm{H}_{4} \mathrm{H}_{\beta}(\mathrm{OH})\left(\mathrm{OCH}_{3}\right)$ (step 1). This endothermic step $\left(\Delta \mathrm{E}_{0}=0.38 \mathrm{eV}\right)$ is kinetically demanding with an activation barrier of $1.11 \mathrm{eV}$, which suggests that pathway 1 is unfavorable. $\mathrm{C}_{6} \mathrm{H}_{4} \mathrm{H}_{\beta}(\mathrm{OH})\left(\mathrm{OCH}_{3}\right)$ can subsequently either go through dehydrogenation steps of the methoxy group to $\mathrm{C}_{6} \mathrm{H}_{4} \mathrm{H}_{\beta}(\mathrm{OH})\left(\mathrm{OCH}_{2}\right.$ ) (step 8) or go through a $-\mathrm{OCH}_{3}$ removal step to produce phenol (step 9). Considering that step 8 is exothermic by -0.16 $\mathrm{eV}$ and has an activation barrier of $0.88 \mathrm{eV}$, while step 9 is exothermic by $-0.97 \mathrm{eV}$ and possesses a lower activation barrier of $0.76 \mathrm{eV}$, step 9 seems to be preferred over step 8 . Next, the methylene group $\left(-\mathrm{CH}_{2}\right)$ can be removed from $\mathrm{C}_{6} \mathrm{H}_{4} \mathrm{H}_{\beta}(\mathrm{OH})\left(\mathrm{OCH}_{2}\right)$ to form $\mathrm{C}_{6} \mathrm{H}_{4} \mathrm{H}_{\beta}(\mathrm{OH})(\mathrm{O})$ (step 22), which is a relatively facile step that is exothermic by $-0.85 \mathrm{eV}$ and possesses an activation barrier of $0.37 \mathrm{eV}$. Hydrogenation of $\mathrm{C}_{6} \mathrm{H}_{4} \mathrm{H}_{\beta}(\mathrm{OH})(\mathrm{O})$ to $\mathrm{C}_{6} \mathrm{H}_{5}(\mathrm{OH})_{2}$ (step 35), which is a hydrogenated catechol species, is a rather difficult 
endothermic step $\left(\Delta \mathrm{E}_{0}=0.23 \mathrm{eV}\right)$ with an activation barrier of $0.90 \mathrm{eV}$. The final step to produce phenol involves dehydroxylation of the phenyl ring (step 40) which is exothermic by $-0.80 \mathrm{eV}$ and has a barrier of $0.63 \mathrm{eV}$.

Similar to the hydrogenation step 1 of the phenyl ring in $\beta$-carbon position in pathway 1, hydrogenation of guaiacol in $\alpha$ carbon position to form $\mathrm{C}_{6} \mathrm{H}_{4} \mathrm{H}_{\alpha}(\mathrm{OH})\left(\mathrm{OCH}_{3}\right)$ (step 2) is also endothermic by $0.49 \mathrm{eV}$ and kinetically demanding with an activation barrier of 1.15 $\mathrm{eV}$, which makes pathway 2 similarly unfavorable. Dehydroxylation of $\mathrm{C}_{6} \mathrm{H}_{4} \mathrm{H}_{\alpha}(\mathrm{OH})\left(\mathrm{OCH}_{3}\right)$ to form anisole (step 10) is exothermic by $-0.88 \mathrm{eV}$ and kinetically feasible with an activation barrier of $0.58 \mathrm{eV}$. Anisole can either desorb or dehydrogenate its $-\mathrm{OCH}_{3}$ group to form $\mathrm{C}_{6} \mathrm{H}_{5} \mathrm{OCH}_{2}$ (step 23) which is mildly exothermic by $-0.38 \mathrm{eV}$ and facile with an activation barrier of $0.44 \mathrm{eV}$. Next, methylene group removal of $\mathrm{C}_{6} \mathrm{H}_{5} \mathrm{OCH}_{2}$ to phenoxy (step 36) is very exothermic by $-1.29 \mathrm{eV}$ and possesses a low barrier of only $0.12 \mathrm{eV}$. Overall, the energetics of pathways 1 and 2 suggest that (except at very high hydrogen partial pressures) the HDO of guaiacol does not proceed by partial hydrogenation of the phenyl ring which agrees with experimental observations.[5]

\subsubsection{Pathways with direct removal of functional groups}

Direct removal of functional groups such as $-\mathrm{OH},-\mathrm{OCH}_{3}$ and $-\mathrm{CH}_{3}$ from guaiacol are found to be kinetically difficult. For pathway 3, the direct removal of a hydroxyl group from guaiacol to form adsorbed $\mathrm{C}_{6} \mathrm{H}_{4} \mathrm{OCH}_{3}$ (step 3) is slightly exothermic by -0.21 $\mathrm{eV}$, but requires overcoming an activation barrier of $1.07 \mathrm{eV}$. Subsequent hydrogenation to anisole (step 11) is again exothermic by $-0.18 \mathrm{eV}$ and involves overcoming a barrier of 
$0.67 \mathrm{eV}$. Pathway 3 and 2 merge at this point and will consequently not be discussed further.

In the fourth pathway, a methoxy group is directly removed from guaiacol to form an adsorbed $\mathrm{C}_{6} \mathrm{H}_{4} \mathrm{OH}$ species (step 4). This process is exothermic by $-0.44 \mathrm{eV}$, but again requires overcoming a relatively high barrier of $0.87 \mathrm{eV}$. To produce phenol, the $\mathrm{C}_{6} \mathrm{H}_{4} \mathrm{OH}$ species is hydrogenated (step 12) in an exothermic process of $-0.17 \mathrm{eV}$ that involves an activation barrier of $0.60 \mathrm{eV}$.

The sixth pathway involves direct removal of a methyl group from guaiacol to form $\mathrm{C}_{6} \mathrm{H}_{4}(\mathrm{OH})(\mathrm{O})$ (step 6) which is quite exothermic, $\Delta \mathrm{E}_{0}=-1.37 \mathrm{eV}$, but also involves a large activation barrier of $1.41 \mathrm{eV}$. Next, $\mathrm{C}_{6} \mathrm{H}_{4}(\mathrm{OH})(\mathrm{O})$ can be hydrogenated to catechol (step 17) in an endothermic process $\Delta \mathrm{E}_{0}=0.78 \mathrm{eV}$ with a barrier of $1.06 \mathrm{eV}$. Alternatively, it can be hydrogenated to $\mathrm{C}_{6} \mathrm{H}_{4} \mathrm{H}_{\alpha}(\mathrm{OH})(\mathrm{O})$ in an endothermic process of $0.87 \mathrm{eV}$ with a high barrier of $1.42 \mathrm{eV}$ (step 18). Finally, $\mathrm{C}_{6} \mathrm{H}_{4}(\mathrm{OH})(\mathrm{O})$ can be dehydroxylated to $\mathrm{C}_{6} \mathrm{H}_{4} \mathrm{O}$ (step 19) in an endothermic process, $\Delta \mathrm{E}_{0}=0.53 \mathrm{eV}$, with a high barrier of $1.14 \mathrm{eV}$.

Once catechol is formed, its deoxygenation to phenol is slow since both the direct hydroxyl group removal to $\mathrm{C}_{6} \mathrm{H}_{4} \mathrm{OH}\left(\mathrm{E}_{\mathrm{a}}=1.16 \mathrm{eV}\right.$ for step 26) and first hydrogenation to $\mathrm{C}_{6} \mathrm{H}_{5}(\mathrm{OH})_{2} \quad\left(\mathrm{E}_{\mathrm{a}}=1.16 \mathrm{eV}\right.$ for step 27) followed by dehydroxylation (step 40) are kinetically slow. Overall, pathways $1,2,3,4$, and 6 are all kinetically unfavorable due to the presence of large activation barriers in the hydrogenation of the phenyl ring or direct removal of a hydroxyl, methoxy, or methyl group.

\subsubsection{Pathways involving dehydrogenation reactions of functional groups}


In the following, we discuss reaction pathways involving initial dehydrogenation steps to form more active adsorbate intermediates. In the fifth reaction pathway, the methoxy group of guaiacol is dehydrogenated to produce $\mathrm{C}_{6} \mathrm{H}_{4}(\mathrm{OH})\left(\mathrm{OCH}_{2}\right)$ (step 5) which we find to be a facile exothermic reaction $\left(\Delta \mathrm{E}_{0}=-0.42 \mathrm{eV} ; \mathrm{E}_{\mathrm{a}}=0.46 \mathrm{eV}\right)$. On Ru (0001), $\mathrm{C}_{6} \mathrm{H}_{4}(\mathrm{OH})\left(\mathrm{OCH}_{2}\right)$ dehydrogenates essentially barrierless $\left(\mathrm{E}_{\mathrm{a}}=0.01 \mathrm{eV}, \Delta \mathrm{E}_{0}=-\right.$ $0.55 \mathrm{eV}$ ) to $\mathrm{C}_{6} \mathrm{H}_{4}(\mathrm{OH})(\mathrm{OCH})$ (step 15), such that the three competing reaction steps (step 13: $-\mathrm{OCH}_{2}$ removal, $\mathrm{E}_{\mathrm{a}}=1.22 \mathrm{eV}, \Delta \mathrm{E}_{0}=-0.22 \mathrm{eV}$; step 14: $-\mathrm{OH}$ dehydrogenation, $\mathrm{E}_{\mathrm{a}}=$ $0.28 \mathrm{eV}, \Delta \mathrm{E}_{0}=-0.76 \mathrm{eV}$; and step 16: $-\mathrm{CH}_{2}$ removal, $\left.\mathrm{E}_{\mathrm{a}}=0.45 \mathrm{eV}, \Delta \mathrm{E}_{0}=-1.25 \mathrm{eV}\right)$ are all kinetically more difficult.

Next, $\mathrm{C}_{6} \mathrm{H}_{4}(\mathrm{OH})(\mathrm{OCH})$ decomposes by methyne removal to produce $\mathrm{C}_{6} \mathrm{H}_{4}(\mathrm{OH})(\mathrm{O})$ (step 25) which is an exothermic reaction, $\Delta \mathrm{E}_{0}=-1.29 \mathrm{eV}$, with a low activation barrier of $0.31 \mathrm{eV}$. As a result, this step is favored over -OCH removal (step 24) which possesses a barrier of $\mathrm{E}_{\mathrm{a}}=1.03 \mathrm{eV}$. Reaction steps involving the hydrogenation and dehydroxylation of $\mathrm{C}_{6} \mathrm{H}_{4}(\mathrm{OH})(\mathrm{O})$ have already been discussed in section 3.3.2.

Finally, in the seventh reaction pathway the phenolic hydrogen in guaiacol is initially removed to produce $\mathrm{C}_{6} \mathrm{H}_{4}(\mathrm{O})\left(\mathrm{OCH}_{3}\right)$ (step 7) which calculations based on DFT predict to be even more facile than dehydrogenation of the methoxy group. We compute for this exothermic reaction $\left(\Delta \mathrm{E}_{0}=-0.80 \mathrm{eV}\right)$ an activation barrier of merely $0.29 \mathrm{eV}$. Then, the methoxy group in $\mathrm{C}_{6} \mathrm{H}_{4}(\mathrm{O})\left(\mathrm{OCH}_{3}\right)$ is dehydrogenated in an exothermic process $\left(\Delta \mathrm{E}_{0}=-\right.$ $0.38 \mathrm{eV}$ ) with an activation barrier of $0.49 \mathrm{eV}$ to produce $\mathrm{C}_{6} \mathrm{H}_{4}(\mathrm{O})\left(\mathrm{OCH}_{2}\right)$ (step 21). Alternatively, the methoxy group is removed; however, this process involves overcoming an activation barrier of $1.08 \mathrm{eV}$. After step 21, the $\mathrm{C}_{6} \mathrm{H}_{4}(\mathrm{O})\left(\mathrm{OCH}_{2}\right)$ intermediate prefers again further dehydrogenation to $\mathrm{C}_{6} \mathrm{H}_{4}(\mathrm{O})(\mathrm{OCH})\left(\right.$ step 32: $\Delta \mathrm{E}_{0}=-0.52 \mathrm{eV} ; \mathrm{E}_{\mathrm{a}}=0.01 \mathrm{eV}$ ) 
over $-\mathrm{OCH}_{2}$ removal (step 30: $\mathrm{E}_{\mathrm{a}}=1.29 \mathrm{eV}$ ) and $-\mathrm{CH}_{2}$ removal (step 31: $\left.\mathrm{E}_{\mathrm{a}}=0.79 \mathrm{eV}\right)$. After reaction step 32, $-\mathrm{CH}$ removal (step 33: $\mathrm{E}_{\mathrm{a}}=0.47 \mathrm{eV}$ ) and $-\mathrm{OCH}$ removal (step 34: $\mathrm{E}_{\mathrm{a}}=0.39 \mathrm{eV}$ ) are in close competition and only a microkinetic model can predict the preferred reaction pathway. Step 33 will be followed by step 41 (hydrogenation to $\left.\mathrm{C}_{6} \mathrm{H}_{4}(\mathrm{OH})(\mathrm{O}) ; \Delta \mathrm{E}_{0}=0.44 \mathrm{eV} ; \mathrm{E}_{\mathrm{a}}=0.96 \mathrm{eV}\right)$ which connects the seventh reaction pathway with the fifth at this intermediate. Reaction step 34 (last dehydrogenation of the methylene group; $\Delta \mathrm{E}_{0}=-0.35 \mathrm{eV} ; \mathrm{E}_{\mathrm{a}}=0.90 \mathrm{eV}$ ) will be followed by a decarbonylation (step 42) to form $\mathrm{C}_{6} \mathrm{H}_{4} \mathrm{O}$ and $\mathrm{CO}$ which is an exothermic process $\left(\Delta \mathrm{E}_{0}=-0.41 \mathrm{eV}\right)$ with a modest barrier $\left(\mathrm{E}_{\mathrm{a}}=0.68 \mathrm{eV}\right)$. Next, $\mathrm{C}_{6} \mathrm{H}_{4} \mathrm{O}$ is hydrogenated to phenol in steps $29\left(\Delta \mathrm{E}_{0}=\right.$ $\left.-0.91 \mathrm{eV} ; \mathrm{E}_{\mathrm{a}}=0.51 \mathrm{eV}\right)$ and $37\left(\Delta \mathrm{E}_{0}=0.88 \mathrm{eV} ; \mathrm{E}_{\mathrm{a}}=1.05 \mathrm{eV}\right)$. Overall, the seventh pathway is likely to proceed by $\mathrm{C}_{6} \mathrm{H}_{4}(\mathrm{OH})\left(\mathrm{OCH}_{3}\right) \rightarrow \mathrm{C}_{6} \mathrm{H}_{4}(\mathrm{O})\left(\mathrm{OCH}_{3}\right)+\mathrm{H} \rightarrow$ $\mathrm{C}_{6} \mathrm{H}_{4}(\mathrm{O})\left(\mathrm{OCH}_{2}\right)+2 \mathrm{H} \rightarrow \mathrm{C}_{6} \mathrm{H}_{4}(\mathrm{O})(\mathrm{OCH})+3 \mathrm{H} \rightarrow \mathrm{C}_{6} \mathrm{H}_{4}(\mathrm{O})(\mathrm{OC})+4 \mathrm{H} \rightarrow \mathrm{C}_{6} \mathrm{H}_{4} \mathrm{O}+\mathrm{CO}+$ $4 \mathrm{H} \rightarrow \ldots \rightarrow \mathrm{C}_{6} \mathrm{H}_{5} \mathrm{OH}+\mathrm{CO}+2 \mathrm{H}$.

Finally, deoxygenation steps by direct phenyl(C)-O bond scission are not included in our reaction network because these steps have very high reaction barriers. For instance, the elementary step $\mathrm{C}_{6} \mathrm{H}_{4}(\mathrm{O})\left(\mathrm{OCH}_{3}\right) \rightarrow \mathrm{C}_{6} \mathrm{H}_{4}\left(\mathrm{OCH}_{3}\right)+\mathrm{O}$ has a high barrier of $1.77 \mathrm{eV}$, the elementary step $\mathrm{C}_{6} \mathrm{H}_{4} \mathrm{O}_{2} \rightarrow \mathrm{C}_{6} \mathrm{H}_{4} \mathrm{O}+\mathrm{O}$ has a barrier of $1.52 \mathrm{eV}$, and $\mathrm{C}_{6} \mathrm{H}_{5} \mathrm{O} \rightarrow \mathrm{C}_{6} \mathrm{H}_{5}+$ $\mathrm{O}$ has a barrier of $1.87 \mathrm{eV}$.

\subsection{Mean-field microkinetic modeling}

To better understand the meaning of the reaction energies, we developed a microkinetic model that considers lateral interactions approximately using a method similar to the one proposed by Grabow et al.[32] We note that other functional forms for 
describing lateral interactions have been proposed and that we selected the method from Grabow et al. primarily for its simplicity. Microkinetic modeling without lateral interactions suggests that $\mathrm{H}, \mathrm{CO}$ and phenoxy $\left(\mathrm{C}_{6} \mathrm{H}_{5} \mathrm{O}\right)$ are the three most abundant surface intermediates and it is most important to consider their lateral interactions approximately. From adsorption energy calculations of $H$ at various coverages $\left(\theta_{\mathrm{H}}=1 / 4\right.$ ML, 2/4 ML, 3/4 ML, 4/4 ML), we determined a hydrogen coverage dependent differential adsorption energy, $E_{\mathrm{H}}\left(\theta_{\mathrm{H}}\right)$, for the reaction $\left.0.5 \mathrm{H}_{2(\mathrm{gas})}\right)^{*} \rightarrow \mathrm{H}^{*}$ shown in Eq. (2).

$$
E_{\mathrm{H}}\left(\theta_{\mathrm{H}}\right)=-0.649+2 * 0.075 *\left(\theta_{\mathrm{H}}-0.100\right)
$$

From adsorption energy calculations of $\mathrm{CO}$ at various coverages $\left(\theta_{\mathrm{CO}}=1 / 4 \mathrm{ML}, 2 / 4\right.$ ML, 3/4 ML, 4/4 ML), we determined a CO coverage dependent differential adsorption energy, $E_{\mathrm{CO}}\left(\theta_{\mathrm{CO}}\right)$ as shown in Eq. (3).

$$
E_{\mathrm{CO}}\left(\theta_{\mathrm{CO}}\right)=-2.126+2 * 0.843 *\left(\theta_{\mathrm{CO}}-0.092\right)
$$

Similarly, from adsorption energy calculations of phenoxy at various coverages $\left(\theta_{\text {phenoxy }}=1 / 20 \mathrm{ML}, 1 / 16 \mathrm{ML}, 1 / 12 \mathrm{ML}, 1 / 9 \mathrm{ML}\right)$, we determined a phenoxy coverage dependent differential adsorption energy of phenoxy, $E_{\text {phenoxy }}\left(\theta_{\text {phenoxy }}\right)$ shown in Eq. (4).

$$
E_{\text {phenoxy }}\left(\theta_{\text {phenoxy }}\right)=-4.438+2 * 4.508 *\left(\theta_{\text {phenoxy }}-0.041\right)
$$

Note that we built $p(5 \times 4) \times 4, p(3 \times 4) \times 4$ slabs, and $p(3 \times 3) \times 4$ slabs to get adsorption energies of phenoxy at coverages of $\theta_{\text {phenoxy }}=1 / 20 \mathrm{ML}, 1 / 12 \mathrm{ML}$, and 1/9 ML. We used a k-point mesh of $4 \times 5 \times 1$ for $p(5 \times 4) \times 4$ slabs, $5 \times 5 \times 1$ for $p(3 \times 4) \times 4$ slabs, and $6 \times 6 \times 1$ for the $p(3 \times 3) \times 4$ slabs. All other parameters of the DFT calculations are the same as those for the $(4 \times 4) \times 4$ slabs. 
Coadsorption of $\mathrm{H}$ and phenoxy at various coverages on $p(3 \times 3) \times 4$ slabs $\left(\theta_{\text {phenoxy }}=1 / 9\right.$ ML and $\left.\theta_{\mathrm{H}}=1 / 9 \mathrm{ML}, 2 / 9 \mathrm{ML}, 3 / 9 \mathrm{ML}, 4 / 9 \mathrm{ML}, 5 / 9 \mathrm{ML}\right)$ leads to $E_{\mathrm{H}}\left(\theta_{\mathrm{H}}, \theta_{\text {phenoxy }}\right)$ and $E_{\text {phenoxy }}\left(\theta_{\mathrm{H}}, \theta_{\text {phenoxy }}\right)$, respectively.

$$
\begin{aligned}
& E_{\mathrm{H}}\left(\theta_{\mathrm{H}}, \theta_{\text {phenoxy }}\right)=-0.649+2 * 0.075 *\left(\theta_{\mathrm{H}}-0.100\right) \\
& -1.124 \theta_{\text {phenoxy }}+1.5 * 11.043 * \theta_{\text {phenoxy }}\left(\theta_{\text {phenox }} \theta_{\mathrm{H}}\right)^{0.5} \\
& E_{\text {phenoxy }}\left(\theta_{\mathrm{H}}, \theta_{\text {phenoxy }}\right)=-4.438+2 * 4.581 *\left(\theta_{\text {phenoxy }}-0.041\right) \\
& -1.124 \theta_{\mathrm{H}}+1.5 * 11.043 * \theta_{\mathrm{H}}\left(\theta_{\text {phenox } x} \theta_{\mathrm{H}}\right)^{0.5}
\end{aligned}
$$

Finally, coadsorption of $\mathrm{H}$ and phenoxy at various coverages on $p(3 \times 3) \times 4$ slabs $\left(\theta_{\text {phenoxy }}=1 / 9 \mathrm{ML}\right.$ and $\left.\theta_{\mathrm{CO}}=1 / 9 \mathrm{ML}, 2 / 9 \mathrm{ML}, 3 / 9 \mathrm{ML}, 4 / 9 \mathrm{ML}, 5 / 9 \mathrm{ML}\right)$ leads to $E_{\mathrm{CO}}\left(\theta_{\mathrm{CO}}\right.$, $\left.\theta_{\text {phenoxy }}\right)$ and $E_{\text {phenoxy }}\left(\theta_{\mathrm{CO}}, \theta_{\text {phenoxy }}\right)$, respectively.

$$
\begin{aligned}
& E_{\mathrm{CO}}\left(\theta_{\mathrm{CO}}, \theta_{\text {phenoxy }}\right)=-2.126+2 * 0.843 *\left(\theta_{\mathrm{CO}}-0.092\right) \\
& +0.851 \theta_{\text {phenoxy }}+1.5 * 7.503 * \theta_{\text {phenoxy }}\left(\theta_{\text {phenox }} \theta_{\mathrm{CO}}\right)^{0.5} \\
& E_{\text {phenoxy }}\left(\theta_{\mathrm{CO}}, \theta_{\text {phenoxy }}\right)=-4.438+2 * 4.508 *\left(\theta_{\text {phenoxy }}-0.041\right) \\
& +0.851 \theta_{\mathrm{CO}}+1.5 * 7.503 * \theta_{\mathrm{CO}}\left(\theta_{\text {phenox } x} \theta_{\mathrm{H}}\right)^{0.5}
\end{aligned}
$$

Equation 5 and 7 are implemented in our microkinetic model.

Considering that we do not have a meaningful water-gas shift or methanation model for Ru catalysts, we fixed in our microkinetic model the partial pressures of the reactants, guaiacol and $\mathrm{H}_{2}$, to 1 bar. For the reaction products, phenol, catechol, benzene, and water, we choose low conversion conditions of $10^{-6}$ bar. For $\mathrm{CO}$ we choose a slightly higher pressure of $10^{-4}$ bar to observe the effect of $\mathrm{CO}$ to the reaction mechanism. In such a reaction environment we observe an $\mathrm{H}$ coverage of $4.8 \%$, a CO coverage of $2.2 \%$ and a phenoxy coverage of $22.4 \%$, i.e., phenoxy occupies $89.6 \%$ of the surface sites since one phenoxy occupies $4 \mathrm{Ru}$ atoms. Other surface intermediates with noticeable coverage are $\mathrm{CH}(0.73 \%)$ and $\mathrm{C}_{6} \mathrm{H}_{4}(\mathrm{OH})(\mathrm{O})(0.50 \%)$. The fraction of free sites is $0.17 \%$. 
Our microkinetic model suggests that hydrogenation steps of the aromatic ring are not favorable at a hydrogen pressure of 1 bar. Hydrogenations of the $\beta$ carbon (pathway 1 ) and $\alpha$ carbon (pathway 2) are slow with TOFs of $1.3 \times 10^{-9} \mathrm{~s}^{-1}$ and $5.9 \times 10^{-10} \mathrm{~s}^{-1}$, respectively. The model also shows that pathways starting with direct removal of $-\mathrm{OH}$ (pathway 3), $-\mathrm{OCH}_{3}$ (pathway 4), and $-\mathrm{CH}_{3}$ (pathway 6) groups are very slow with TOFs of $1.9 \times 10^{-10} \mathrm{~s}^{-1}, 4.3 \times 10^{-9} \mathrm{~s}^{-1}$ and $1.4 \times 10^{-13} \mathrm{~s}^{-1}$, respectively.

Next, the fifth pathway has a TOF of $1.9 \times 10^{-8} \mathrm{~s}^{-1}$, which is 4 orders of magnitude slower than pathway $7\left(3.6 \times 10^{-4} \mathrm{~s}^{-1}\right)$. We conclude that demethylation of guaiacol to form catechol is much slower than HDO to phenol. The observation that pathway 7 is dominant suggests that the $\mathrm{O}-\mathrm{H}$ bond in guaiacol is quite easily broken when adsorbed on a $\mathrm{Ru}$ surface. The intermediate thus created, $\mathrm{C}_{6} \mathrm{H}_{4}(\mathrm{O})\left(\mathrm{OCH}_{3}\right)$, will proceed by $-\mathrm{OCH}_{3}$ dehydrogenation to form $\mathrm{C}_{6} \mathrm{H}_{4}(\mathrm{O})\left(\mathrm{OCH}_{2}\right)$. Alternative removal of $-\mathrm{OCH}_{3}$ (step 20) is slow $\left(\right.$ TOF $\left.=3.2 \times 10^{-6} \mathrm{~s}^{-1}\right) . \quad \mathrm{C}_{6} \mathrm{H}_{4}(\mathrm{O})\left(\mathrm{OCH}_{2}\right)$ follows further dehydrogenation to form $\mathrm{C}_{6} \mathrm{H}_{4}(\mathrm{O})(\mathrm{OCH})$ because neither $-\mathrm{OCH}_{2}$ removal $\left(9.8 \times 10^{-16} \mathrm{~s}^{-1}\right)$ nor $-\mathrm{CH}_{2}$ removal $\left(3.6 \times 10^{-11} \mathrm{~s}^{-1}\right)$ are favorable. $\mathrm{C}_{6} \mathrm{H}_{4}(\mathrm{O})(\mathrm{OCH})$ then reacts by $-\mathrm{CH}$ removal to form $\mathrm{C}_{6} \mathrm{H}_{4} \mathrm{O}_{2}\left(7.5 \times 10^{-5} \mathrm{~s}^{-1}\right)$ and - CHO dehydrogenation to form $\mathrm{C}_{6} \mathrm{H}_{4}(\mathrm{O})(\mathrm{OC})\left(2.8 \times 10^{-4} \mathrm{~s}^{-1}\right)$, which are two competitive pathways. $\mathrm{C}_{6} \mathrm{H}_{4} \mathrm{O}_{2}$ is first hydrogenated to $\mathrm{C}_{6} \mathrm{H}_{4}(\mathrm{O})(\mathrm{OH})$ and then dehydroxylated to $\mathrm{C}_{6} \mathrm{H}_{4} \mathrm{O}$, before it is hydrogenated to phenol. $\mathrm{C}_{6} \mathrm{H}_{4}(\mathrm{O})(\mathrm{OC})$ will follow a decarbonylation step to form $\mathrm{C}_{6} \mathrm{H}_{4} \mathrm{O}$, which is then hydrogenated to phenol. Phenol will desorb since both the $-\mathrm{OH}$ removal pathway $\left(\mathrm{TOF}=2.0 \times 10^{-7} \mathrm{~s}^{-1}\right.$ ) and the $\alpha$ carbon hydrogenation followed by $-\mathrm{OH}$ removal $\left(5.4 \times 10^{-7} \mathrm{~s}^{-1}\right)$ are unfavorable. It is interesting to note though that the $-\mathrm{OH}$ removal by hydrogenation of the phenyl ring is slightly preferred to the direct $-\mathrm{OH}$ removal even at low hydrogen partial pressures. We 
predict that at higher hydrogen partial pressures benzene production will primarily occur by partial phenyl ring hydrogenation which can of course also lead to cyclohexane production not investigated in this study. Next, calculations based on DFT suggest that hydrogenation of $\mathrm{C}_{6} \mathrm{H}_{4}(\mathrm{O})(\mathrm{OH})$ to catechol is less favorable than its dehydroxylation to $\mathrm{C}_{6} \mathrm{H}_{4} \mathrm{O}\left(3.9 \times 10^{-6} \mathrm{~s}^{-1}\right.$ versus $\left.7.5 \times 10^{-5} \mathrm{~s}^{-1}\right)$. Overall, the major product is predicted to be phenol and catechol is the most important side product.

(Figure 6 here)

Sun et al.[5] recently observed experimentally that phenol was the major product (61.6\% yield) of guaiacol $\mathrm{HDO}$ on a $\mathrm{Ru} / \mathrm{C}$ catalysts at $250^{\circ} \mathrm{C}$ at low guaiacol and $\mathrm{H}_{2}$ partial pressures. In addition, an appreciable amount of benzene ( $\sim 5 \%$ yield) and aromatic ring saturated products such as cyclohexanone ( $10 \%$ yield) and cyclohexanol ( $\sim 5 \%$ yield) were observed. They also observed that the selectivity to benzene, cyclohexanone and cyclohexanol increased at the expense of phenol, suggesting that benzene was formed by hydrodeoxygenation of phenol and cyclohexanone and cyclohexanol were formed by ring saturation of phenol. This is partly confirmed by our calculations since phenyl ring saturation of guaiacol (pathways 1 and 2) before dehydrogenation and phenol formation is found to be unfavorable.

Elliott et al.[6] investigated the $\mathrm{HDO}$ of guaiacol over $\mathrm{Ru} / \mathrm{C}$ catalysts at $250^{\circ} \mathrm{C}$ and high $\mathrm{H}_{2}$ partial pressure and observed aromatic ring saturated products such as cyclohexanol, 2-methoxycyclohexanol, and cyclohexane as the major products. In agreement to our calculations they also observed phenol as a major early product that is later converted to cyclohexanone and cyclohexanol. 
Also, similar reaction mechanisms have been found on precious metal catalysts such as Pd- and Pt-based catalysts.[5]'[10] For example, Sun et al.[5] proposed that on $\mathrm{Pd} / \mathrm{C}$ and $\mathrm{Pt} / \mathrm{C}$ the favorable pathway should be first demethoxylation to form phenol followed by hydrogenation to cyclohexanone/cyclohexanol. These results stand in contrast to experiments by Lin et al.[9] who proposed that on Rh-based catalysts the HDO of guaiacol proceeds by hydrogenation of the aromatic ring to form 2methoxycyclohexanone and 2-methoxycyclohexanol intermediates, followed by demethoxylation and/or dehydroxylation to yield cyclohexanone/cyclohexanol and cyclohexane products.

\subsection{Sensitivity analysis}

\subsubsection{Degree of rate control}

We have used Campbell's degree of rate control[33, 34], $X_{\mathrm{RC}}$, to determine the ratecontrolling steps in the mechanism. The degree of rate control is defined as

$$
X_{\mathrm{RC}, i}=\frac{k_{i}}{r}\left(\frac{\partial r}{\partial k_{i}}\right)_{K_{i}, k_{j} \neq k_{i}}
$$

where $r$ is the overall rate of reaction. Under the reaction conditions mentioned above, we found the largest degree of rate control of $\sim 0.5$ for the OC-H cleavage of $\left.\mathrm{C}_{6} \mathrm{H}_{4}(\mathrm{O})(\mathrm{OCH})\right)$, suggesting that dehydrogenation steps are at least partially rate controlling. Next, we observed for a few other steps, such as the guaiacol adsorption and possibly hydrogenation of phenoxy to phenol, some sensitivity for the turnover frequency likely due to the relatively small free site and hydrogen coverage. However, due to numerical inaccuracies in solving the large network of elementary steps and our 
approximate approach for describing lateral interactions, no reliable rate control values could be computed.

\subsubsection{Degree of thermodynamic rate control}

The degree of thermodynamic rate control[35], $X_{\mathrm{TRC}}$, is used to analyze the sensitivity of the microkinetic model with regards to adsorbed intermediates:

$$
X_{\mathrm{TRC}, n}=\frac{1}{r}\left(\frac{\partial r}{\partial\left(\frac{-G_{n}^{0}}{R T}\right)}\right)_{G_{m \neq n}^{0}, G_{i}^{0, \mathrm{TS}}}
$$

where $r$ is the overall rate of reaction; $G_{n}{ }^{0}$ is the free energy of adsorbate $n$. Under the reaction conditions mentioned above, the surface intermediate $\mathrm{C}_{6} \mathrm{H}_{4}(\mathrm{OH})(\mathrm{O})$ has a degree of thermodynamic rate control of -0.4. This relatively large thermodynamic rate control for $\mathrm{C}_{6} \mathrm{H}_{4}(\mathrm{OH})(\mathrm{O})$ can be understood by our observation that stabilizing it deceases the already small surface coverage of various species on the dominant reaction pathway. Next, $\mathrm{CO}$ has a $\mathrm{X}_{\mathrm{TRC}}$ of -0.25 indicating its ability to poison the Ru surface. Finally, we observe some sensitivity of our results to the adsorption strength of $\mathrm{H}$ and $\mathrm{CH}$. Unfortunately, no meaningful thermodynamic rate control values can be reported due to the large numerical noise in the calculations of these $\mathrm{X}_{\mathrm{TRC}}$ values. However, the $\mathrm{X}_{\mathrm{TRC}}$ values are likely small and positive which can be explained by a higher hydrogen coverage and a reduced reverse reaction for step 33 if $\mathrm{H}$ and $\mathrm{CH}$ are stabilized on the $\mathrm{Ru}$ surface.

\subsection{Computed apparent reaction orders}


Finally, we calculated the order of reactions $\left(\alpha_{i}\right)$ at $573 \mathrm{~K}$ with respect to guaiacol and $\mathrm{H}_{2}$, respectively, to understand the sensitivity of our results to changes in partial pressure.

$$
\alpha_{i}=\left(\frac{\partial \ln (r)}{\partial \ln \left(p_{i}\right)}\right)_{T, P}
$$

Our model predicts a small guaiacol and $\mathrm{H}_{2}$ reaction order of $\sim 0.1$ in the range of 0.2 1.6 bar for guaiacol and $0.2-1.0$ bar for $\mathrm{H}_{2}$, indicating that in this low pressure regime our results are not very sensitive to the reactant partial pressures. Finally, we compute a CO reaction order of -0.4 in the pressure range of $10^{-5}-10^{-3}$ bar, indicating that a good watergas shift or methanation activity is required for a good HDO catalyst to keep the CO partial pressure low and avoid catalyst poisoning by $\mathrm{CO}$.

\section{Conclusions}

We have built a microkinetic model based on parameters obtained from density functional theory calculations to investigate the hydrodeoxygenation mechanism of guaiacol over Ru(0001) model surfaces. We find that at low hydrogen partial pressure the kinetically most favorable pathway proceeds via dehydrogenation of the hydroxyl group of guaiacol $\left[\mathrm{C}_{6} \mathrm{H}_{4}(\mathrm{OH})\left(\mathrm{OCH}_{3}\right)\right]$ to yield $\mathrm{C}_{6} \mathrm{H}_{4}(\mathrm{O})\left(\mathrm{OCH}_{3}\right)$, followed by full dehydrogenation of the methoxy group to yield $\mathrm{C}_{6} \mathrm{H}_{4}(\mathrm{O})(\mathrm{OC})$. Next, $\mathrm{C}_{6} \mathrm{H}_{4}(\mathrm{O})(\mathrm{OC})$ decarbonylates to produce $\mathrm{C}_{6} \mathrm{H}_{4} \mathrm{O}$ and $\mathrm{CO}$, followed by hydrogenation to produce phenol $\left(\mathrm{C}_{6} \mathrm{H}_{5} \mathrm{OH}\right)$. At the adsorbed $\mathrm{C}_{6} \mathrm{H}_{4}(\mathrm{O})(\mathrm{OCH})$ intermediate, a competitive deoxygenation pathway is identified that involves methyne group removal to $\mathrm{C}_{6} \mathrm{H}_{4} \mathrm{O}_{2}$, followed by hydrogenation to $\mathrm{C}_{6} \mathrm{H}_{4}(\mathrm{OH})(\mathrm{O})$, dehydroxylation to $\mathrm{C}_{6} \mathrm{H}_{4} \mathrm{O}$ and finally hydrogenation to phenol. Phenol is found to be the major reaction product and further deoxygenation of phenol to benzene is found to be very challenging over a $\mathrm{Ru}(0001)$ catalyst surface. 
Catechol is predicted to be the most relevant side product. Computations predict that the final dehydrogenation step of the methoxy species in guaiacol is at least partially rate controlling over Ru catalysts. Interestingly, direct removal of an oxygen atom bound to a phenyl ring is unlikely to occur over the $\mathrm{Ru}(0001)$ as deoxygenation only occurs by decarbonylation and dehydroxylation. Finally, hydrogenation of the phenyl ring is energetically demanding such that aromatic products can be produced over Ru catalysts at mild hydrogenation conditions. At higher hydrogen partial pressures, we predict $-\mathrm{OH}$ removal from phenol to occurs by partial phenyl ring hydrogenation which can lead to benzene and cyclohexane production.

\section{Acknowledgements}

We acknowledge Dr. Aravind Asthagiri from the Ohio State University for helping us obtain and install the vasp D3 corrections for dispersion interactions. This work has been supported by the U.S. Department of Energy, Office of Basic Energy Sciences, Chemical Sciences Division under Contract DE-FG02-11ER16268 (DESC0007167). Computational resources have been provided by the National Energy Research Scientific Computing Center (NERSC) which is supported by the Office of Science of the U.S. Department of Energy and in part by XSEDE under grant number TG-CTS090100. Finally, computing resources from the USC NanoCenter and USC's High Performance Computing Group are gratefully acknowledged. 
TABLE 1: Zero-point energy corrected adsorption energies (in eV) of selected reaction intermediates in the hydrodeoxygenation of guaiacol computed with PBE and PBE-D3 functional. Herein, $\alpha$ carbon means the aromatic ring carbon binding to the $-\mathrm{OH}$ group and $\beta$ carbon means the aromatic ring carbon binding to the $-\mathrm{OCH}_{3}$ group. $\mathrm{H}_{\alpha}$ symbolizes a hydrogen atom binding to the $\alpha$ carbon and $\mathrm{H}_{\beta}$ symbolizes a hydrogen atom binding to the $\beta$ carbon.

\begin{tabular}{|lccc|}
\hline Formula & PBE & PBE-D3 & $\begin{array}{c}\Delta \mathrm{E}_{0}=\text { PBE-D3 } \\
- \text { PBE }\end{array}$ \\
\hline $\mathrm{C}_{6} \mathrm{H}_{4}(\mathrm{OH})\left(\mathrm{OCH}_{3}\right)$ & -1.33 & -2.46 & -1.13 \\
$\mathrm{C}_{6} \mathrm{H}_{4} \mathrm{H}_{3}(\mathrm{OH})\left(\mathrm{OCH}_{3}\right)$ & -2.80 & -4.10 & -1.30 \\
$\mathrm{C}_{6} \mathrm{H}_{4} \mathrm{H}_{\alpha}(\mathrm{OH})\left(\mathrm{OCH}_{3}\right)$ & -2.77 & -4.04 & -1.27 \\
$\mathrm{C}_{6} \mathrm{H}_{4} \mathrm{OCH} \mathrm{CH}_{3}$ & -3.10 & -4.16 & -1.06 \\
$\mathrm{C}_{6} \mathrm{H}_{4} \mathrm{OH}$ & -3.34 & -4.27 & -0.94 \\
$\mathrm{C}_{6} \mathrm{H}_{4}(\mathrm{OH})\left(\mathrm{OCH}_{2}\right)$ & -2.88 & -4.12 & -1.25 \\
$\mathrm{C}_{6} \mathrm{H}_{4}(\mathrm{OH})(\mathrm{O})$ & -2.71 & -3.74 & -1.03 \\
$\mathrm{C}_{6} \mathrm{H}_{4}(\mathrm{O})(\mathrm{OCH}$ & & -4.03 & -1.18 \\
$\mathrm{C}_{6} \mathrm{H}_{5} \mathrm{OCH}$ & -2.85 & -2.54 & -1.11 \\
$\mathrm{C}_{6} \mathrm{H}_{4}(\mathrm{OH})_{2}$ & -1.43 & -2.60 & -1.00 \\
$\mathrm{C}_{6} \mathrm{H}_{5} \mathrm{OH}$ & -1.60 & -2.51 & -0.92 \\
$\mathrm{C}_{6} \mathrm{H}_{6}$ & -1.59 & -2.42 & -0.89 \\
$\mathrm{CO}$ & -1.53 & -2.06 & -0.20 \\
$\mathrm{H}$ & -1.86 & -2.78 & -0.05 \\
$\mathrm{OH}$ & -2.73 & -3.56 & -0.14 \\
$\mathrm{H}_{2} \mathrm{O}$ & -3.42 & -0.59 & -0.21 \\
$\mathrm{CH}_{3}$ & -0.38 & -2.37 & -0.28 \\
$\mathrm{CH}_{3} \mathrm{O}$ & -2.09 & -2.92 & -0.29 \\
$\mathrm{CH}_{3} \mathrm{OH}$ & -0.40 & -0.75 & -0.35 \\
\hline
\end{tabular}


TABLE 2: Zero-point energy corrected reaction energies (in $\mathrm{eV}$ ) of selected surface reactions in the hydrodeoxygenation of guaiacol computed with PBE and PBE-D3 functional.

\begin{tabular}{|clccc|}
\hline Step No. & Formula & PBE & PBE-D3 & $\begin{array}{c}\Delta \mathrm{E}_{0}=\text { PBE-D3 } \\
\end{array}$ \\
\hline 1 & $\mathrm{C}_{6} \mathrm{H}_{4}(\mathrm{OH})\left(\mathrm{OCH}_{3}\right)+\mathrm{H} \rightarrow \mathrm{C}_{6} \mathrm{H}_{4} \mathrm{H}_{\beta}(\mathrm{OH})\left(\mathrm{OCH}_{3}\right)$ & 0.44 & 0.38 & -0.06 \\
2 & $\mathrm{C}_{6} \mathrm{H}_{4}(\mathrm{OH})\left(\mathrm{OCH}_{3}\right)+\mathrm{H} \rightarrow \mathrm{C}_{6} \mathrm{H}_{4} \mathrm{H}_{a}(\mathrm{OH})\left(\mathrm{OCH}_{3}\right)$ & 0.52 & 0.49 & -0.03 \\
3 & $\mathrm{C}_{6} \mathrm{H}_{4}(\mathrm{OH})\left(\mathrm{OCH}_{3}\right) \rightarrow \mathrm{C}_{6} \mathrm{H}_{4} \mathrm{OCH}_{3}+\mathrm{OH}$ & -0.24 & -0.21 & -0.03 \\
4 & $\mathrm{C}_{6} \mathrm{H}_{4}(\mathrm{OH})\left(\mathrm{OCH}_{3}\right) \rightarrow \mathrm{C}_{6} \mathrm{H}_{4} \mathrm{OH}+\mathrm{CH}_{3} \mathrm{O}$ & -0.48 & -0.44 & -0.04 \\
5 & $\mathrm{C}_{6} \mathrm{H}_{4}(\mathrm{OH})\left(\mathrm{OCH}_{3}\right) \rightarrow \mathrm{C}_{6} \mathrm{H}_{4}(\mathrm{OH})\left(\mathrm{OCH}_{2}\right)+\mathrm{H}$ & -0.33 & -0.42 & 0.09 \\
6 & $\mathrm{C}_{6} \mathrm{H}_{4}(\mathrm{OH})\left(\mathrm{OCH}_{3}\right) \rightarrow \mathrm{C}_{6} \mathrm{H}_{4}(\mathrm{OH})(\mathrm{O})+\mathrm{CH}_{3}$ & -1.32 & -1.37 & -0.05 \\
7 & $\mathrm{C}_{6} \mathrm{H}_{4}(\mathrm{OH})\left(\mathrm{OCH}_{3}\right) \rightarrow \mathrm{C}_{6} \mathrm{H}_{4}(\mathrm{O})\left(\mathrm{OCH}_{3}\right)+\mathrm{H}$ & -0.79 & -0.80 & -0.01 \\
48 & $\mathrm{H}+\mathrm{OH} \rightarrow \mathrm{H}_{2} \mathrm{O}$ & 0.57 & 0.57 & 0.00 \\
51 & $\mathrm{H}+\mathrm{CH} \mathrm{H}_{3} \mathrm{O} \rightarrow \mathrm{CH}_{3} \mathrm{OH}$ & 0.74 & 0.77 & 0.03 \\
\hline
\end{tabular}


TABLE 3: Adsorption sites occupied, zero-point energy corrected adsorption energies $\left(E_{0, a d s}\right)$, and zero-point energy corrections $(\triangle \mathrm{ZPE})$ of various reaction intermediates in the hydrodeoxygenation of guaiacol computed with PBE-D3.

\begin{tabular}{|c|c|c|c|}
\hline Formula & No. of sites & $\mathrm{E}_{0, \mathrm{ads}}(\mathrm{eV})$ & $\triangle \mathrm{ZPE}(\mathrm{eV})$ \\
\hline $\mathrm{C}_{6} \mathrm{H}_{4}(\mathrm{OH})\left(\mathrm{OCH}_{3}\right)$, guaiacol & 4 & -2.46 & -0.02 \\
\hline $\mathrm{C}_{6} \mathrm{H}_{4} \mathrm{H}_{\beta}(\mathrm{OH})\left(\mathrm{OCH}_{3}\right)$ & 4 & -4.10 & -0.05 \\
\hline $\mathrm{C}_{6} \mathrm{H}_{4} \mathrm{H}_{\alpha}(\mathrm{OH})\left(\mathrm{OCH}_{3}\right)$ & 4 & -4.04 & -0.03 \\
\hline $\mathrm{C}_{6} \mathrm{H}_{4} \mathrm{OCH}_{3}$ & 4 & -4.16 & -0.04 \\
\hline $\mathrm{C}_{6} \mathrm{H}_{4} \mathrm{OH}$ & 4 & -4.27 & -0.06 \\
\hline $\mathrm{C}_{6} \mathrm{H}_{4}(\mathrm{OH})\left(\mathrm{OCH}_{2}\right)$ & 5 & -4.12 & -0.03 \\
\hline $\mathrm{C}_{6} \mathrm{H}_{4}(\mathrm{OH})(\mathrm{O})$ & 4 & -3.74 & -0.04 \\
\hline $\mathrm{C}_{6} \mathrm{H}_{4}(\mathrm{O})\left(\mathrm{OCH}_{3}\right)$ & 4 & -4.03 & -0.05 \\
\hline $\mathrm{C}_{6} \mathrm{H}_{4} \mathrm{H}_{\beta}(\mathrm{OH})\left(\mathrm{OCH}_{2}\right)$ & 5 & -5.32 & 0.02 \\
\hline $\mathrm{C}_{6} \mathrm{H}_{5} \mathrm{OCH}_{3}$, anisole & 4 & -2.54 & -0.05 \\
\hline $\mathrm{C}_{6} \mathrm{H}_{4}(\mathrm{OH})(\mathrm{OCH})$ & 5 & -5.72 & -0.04 \\
\hline $\mathrm{C}_{6} \mathrm{H}_{4}(\mathrm{OH})_{2}$, catechol & 4 & -2.60 & -0.03 \\
\hline $\mathrm{C}_{6} \mathrm{H}_{4} \mathrm{O}$ & 4 & -5.04 & 0.12 \\
\hline $\mathrm{C}_{6} \mathrm{H}_{4}(\mathrm{O})\left(\mathrm{OCH}_{2}\right)$ & 5 & -4.84 & 0.00 \\
\hline $\mathrm{C}_{6} \mathrm{H}_{4} \mathrm{H}_{\beta}(\mathrm{OH})(\mathrm{O})$ & 4 & -3.41 & -0.01 \\
\hline $\mathrm{C}_{6} \mathrm{H}_{5} \mathrm{OCH}_{2}$ & 4 & -4.09 & 0.04 \\
\hline $\mathrm{C}_{6} \mathrm{H}_{5} \mathrm{O}$, phenoxy & 4 & -4.40 & -0.01 \\
\hline $\mathrm{C}_{6} \mathrm{H}_{5} \mathrm{OH}$, phenol & 4 & -2.51 & -0.02 \\
\hline $\mathrm{C}_{6} \mathrm{H}_{5}(\mathrm{OH})_{2}$ & 4 & -4.28 & -0.03 \\
\hline $\mathrm{C}_{6} \mathrm{H}_{4} \mathrm{O}_{2}$ & 5 & -4.56 & -0.03 \\
\hline $\mathrm{C}_{6} \mathrm{H}_{5}$ & 4 & -4.11 & -0.01 \\
\hline $\mathrm{C}_{6} \mathrm{H}_{6} \mathrm{OH}$ & 4 & -4.37 & 0.04 \\
\hline $\mathrm{C}_{6} \mathrm{H}_{6}$, benzene & 3 & -2.42 & -0.01 \\
\hline $\mathrm{C}_{6} \mathrm{H}_{4} \mathrm{H}_{\alpha}(\mathrm{O})(\mathrm{OH})$ & 4 & -3.59 & -0.02 \\
\hline $\mathrm{C}_{6} \mathrm{H}_{4}(\mathrm{O})(\mathrm{OCH})$ & 5 & -6.66 & 0.01 \\
\hline $\mathrm{C}_{6} \mathrm{H}_{4}(\mathrm{O})(\mathrm{OC})$ & 5 & -4.64 & -0.09 \\
\hline $\mathrm{H}$ & 1 & -2.78 & 0.17 \\
\hline $\mathrm{OH}$ & 1 & -3.56 & 0.12 \\
\hline $\mathrm{H}_{2} \mathrm{O}$ & 1 & -0.59 & 0.05 \\
\hline
\end{tabular}




\begin{tabular}{|llll|}
\hline $\mathrm{CH}$ & 1 & -6.94 & 0.18 \\
$\mathrm{CH}_{2}$ & 1 & -4.52 & 0.12 \\
$\mathrm{CH}_{3}$ & 1 & -2.37 & 0.08 \\
$\mathrm{CH}_{4}$ & 1 & -0.22 & -0.01 \\
$\mathrm{CO}$ & 1 & -2.06 & 0.07 \\
$\mathrm{CHO}$ & 2 & -2.65 & 0.11 \\
$\mathrm{CH}_{2} \mathrm{O}$ & 2 & -1.36 & 0.05 \\
$\mathrm{CH}_{3} \mathrm{O}$ & 2 & -2.92 & 0.17 \\
$\mathrm{CH}_{3} \mathrm{OH}$ & 1 & -0.75 & 0.03 \\
\hline
\end{tabular}


Table 4. Calculated zero-point corrected reaction energies $(\Delta E)$, activation barriers $\left(E^{\dagger}\right)$ and rate parameters for all elementary reaction steps in the hydrodeoxygenation of guaiacol over Ru (0001)

\begin{tabular}{|c|c|c|c|c|c|c|}
\hline \multirow[b]{2}{*}{ Step } & \multirow[b]{2}{*}{ Reaction } & \multirow[b]{2}{*}{ constant } & \multicolumn{4}{|c|}{$\mathrm{T}(\mathrm{K})$} \\
\hline & & & 473 & 523 & 573 & 623 \\
\hline \multirow[t]{2}{*}{0} & $\mathrm{C}_{6} \mathrm{H}_{4}(\mathrm{OH})\left(\mathrm{OCH}_{3}\right)(\mathrm{gas})+4 * \rightarrow \mathrm{C}_{6} \mathrm{H}_{4}(\mathrm{OH})\left(\mathrm{OCH}_{3}\right)^{* * * *}$ & $\mathrm{~K}_{0}$ & $7.35 \times 10^{8}$ & $5.23 \times 10^{5}$ & $1.06 \times 10^{3}$ & $4.78 \times 10^{0}$ \\
\hline & $\Delta \mathrm{E}_{0}=-2.46 \mathrm{eV}$ & $\mathrm{k}_{0}{ }^{+}, \mathrm{s}^{-1} \mathrm{bar}^{-1}$ & $6.88 \times 10^{7}$ & $6.54 \times 10^{7}$ & $6.25 \times 10^{7}$ & $5.99 \times 10^{7}$ \\
\hline \multirow[t]{2}{*}{1} & $\mathrm{C}_{6} \mathrm{H}_{4}(\mathrm{OH})\left(\mathrm{OCH}_{3}\right)^{* * * *}+\mathrm{H}^{*} \rightarrow \mathrm{C}_{6} \mathrm{H}_{4} \mathrm{H}_{\beta}(\mathrm{OH})\left(\mathrm{OCH}_{3}\right)^{* * * *}+*$ & $\mathrm{~K}_{1}$ & $1.24 \times 10^{-4}$ & $2.94 \times 10^{-4}$ & $5.96 \times 10^{-4}$ & $1.08 \times 10^{-3}$ \\
\hline & $\Delta \mathrm{E}_{1}=0.38 \mathrm{eV}, \mathrm{E}_{1}^{\dagger}=1.11 \mathrm{eV}$ & $\mathrm{k}_{1}^{+}, \mathrm{s}^{-1}$ & $1.36 \times 10^{1}$ & $1.99 \times 10^{2}$ & $1.83 \times 10^{3}$ & $1.18 \times 10^{4}$ \\
\hline \multirow[t]{2}{*}{2} & $\mathrm{C}_{6} \mathrm{H}_{4}(\mathrm{OH})\left(\mathrm{OCH}_{3}\right)^{* * * *}+\mathrm{H}^{*} \rightarrow \mathrm{C}_{6} \mathrm{H}_{4} \mathrm{H}_{\alpha}(\mathrm{OH})\left(\mathrm{OCH}_{3}\right)^{* * * *}+*$ & $\mathrm{~K}_{2}$ & $4.59 \times 10^{-6}$ & $1.36 \times 10^{-5}$ & $3.32 \times 10^{-5}$ & $6.96 \times 10^{-5}$ \\
\hline & $\Delta \mathrm{E}_{2}=0.49 \mathrm{eV}, \mathrm{E}_{2}^{\dagger}=1.15 \mathrm{eV}$ & $\mathrm{k}_{2}{ }^{+}, \mathrm{s}^{-1}$ & $6.01 \times 10^{0}$ & $9.66 \times 10^{1}$ & $9.57 \times 10^{2}$ & $6.56 \times 10^{3}$ \\
\hline \multirow[t]{2}{*}{3} & $\mathrm{C}_{6} \mathrm{H}_{4}(\mathrm{OH})\left(\mathrm{OCH}_{3}\right)^{* * * * *}+* \mathrm{C}_{6} \mathrm{H}_{4} \mathrm{OCH}_{3} * * * *+\mathrm{OH}^{*}$ & $\mathrm{~K}_{3}$ & $2.17 \times 10^{2}$ & $1.40 \times 10^{2}$ & $9.87 \times 10^{1}$ & $7.39 \times 10^{1}$ \\
\hline & $\Delta \mathrm{E}_{3}=-0.21 \mathrm{eV}, \mathrm{E}_{3}^{\dagger}=1.07 \mathrm{eV}$ & $\mathrm{k}_{3}^{+}, \mathrm{s}^{-1}$ & $7.11 \times 10^{1}$ & $9.70 \times 10^{2}$ & $8.45 \times 10^{3}$ & $5.23 \times 10^{4}$ \\
\hline \multirow[t]{2}{*}{4} & $\mathrm{C}_{6} \mathrm{H}_{4}(\mathrm{OH})\left(\mathrm{OCH}_{3}\right)^{* * * *+*} \rightarrow \mathrm{C}_{6} \mathrm{H}_{4} \mathrm{OH}^{* * * *}+\mathrm{CH}_{3} \mathrm{O}^{*}$ & $\mathrm{~K}_{4}$ & $1.22 \times 10^{5}$ & $4.68 \times 10^{4}$ & $2.14 \times 10^{4}$ & $1.11 \times 10^{4}$ \\
\hline & $\Delta \mathrm{E}_{4}=-0.44 \mathrm{eV}, \mathrm{E}_{4}^{\dagger}=0.87 \mathrm{eV}$ & $\mathrm{k}_{4}^{+}, \mathrm{s}^{-1}$ & $1.34 \times 10^{4}$ & $1.01 \times 10^{5}$ & $5.39 \times 10^{5}$ & $2.22 \times 10^{6}$ \\
\hline \multirow[t]{2}{*}{5} & $\mathrm{C}_{6} \mathrm{H}_{4}(\mathrm{OH})\left(\mathrm{OCH}_{3}\right)^{* * * * *}+2^{*} \rightarrow \mathrm{C}_{6} \mathrm{H}_{4}(\mathrm{OH})\left(\mathrm{OCH}_{2}\right)^{* * * * *}+\mathrm{H}^{*}$ & $\mathrm{~K}_{5}$ & $1.10 \times 10^{4}$ & $4.02 \times 10^{3}$ & $1.76 \times 10^{3}$ & $8.86 \times 10^{2}$ \\
\hline & $\Delta \mathrm{E}_{5}=-0.42 \mathrm{eV}, \mathrm{E}_{5}^{\dagger}=0.46 \mathrm{eV}$ & $\mathrm{k}_{5}^{+}, \mathrm{s}^{-1}$ & $6.46 \times 10^{7}$ & $2.08 \times 10^{8}$ & $5.51 \times 10^{8}$ & $1.26 \times 10^{9}$ \\
\hline \multirow[t]{2}{*}{6} & $\mathrm{C}_{6} \mathrm{H}_{4}(\mathrm{OH})\left(\mathrm{OCH}_{3}\right)^{* * * *}+* \rightarrow \mathrm{C}_{6} \mathrm{H}_{4}(\mathrm{OH})(\mathrm{O})^{* * * *}+\mathrm{CH}_{3} *$ & $\mathrm{~K}_{6}$ & $2.80 \times 10^{14}$ & $1.18 \times 10^{13}$ & $8.76 \times 10^{11}$ & $9.93 \times 10^{10}$ \\
\hline & $\Delta \mathrm{E}_{6}=-1.37 \mathrm{eV}, \mathrm{E}_{6}^{\dagger}=1.41 \mathrm{eV}$ & $\mathrm{k}_{6}^{+}, \mathrm{s}^{-1}$ & $1.19 \times 10^{-2}$ & $3.57 \times 10^{-1}$ & $5.98 \times 10^{0}$ & $6.42 \times 10^{1}$ \\
\hline \multirow[t]{2}{*}{7} & $\mathrm{C}_{6} \mathrm{H}_{4}(\mathrm{OH})\left(\mathrm{OCH}_{3}\right)^{* * * *+*} \rightarrow \mathrm{C}_{6} \mathrm{H}_{4}(\mathrm{O})\left(\mathrm{OCH}_{3}\right)^{* * * *}+\mathrm{H}^{*}$ & $\mathrm{~K}_{7}$ & $1.43 \times 10^{8}$ & $2.11 \times 10^{7}$ & $4.37 \times 10^{6}$ & $1.17 \times 10^{6}$ \\
\hline & $\Delta \mathrm{E}_{7}=-0.80 \mathrm{eV}, \mathrm{E}_{7}^{\dagger}=0.29 \mathrm{eV}$ & $\mathrm{k}_{7}^{+}, \mathrm{s}^{-1}$ & $5.41 \times 10^{9}$ & $1.14 \times 10^{10}$ & $2.11 \times 10^{10}$ & $3.56 \times 10^{10}$ \\
\hline \multirow[t]{2}{*}{8} & $\mathrm{C}_{6} \mathrm{H}_{4} \mathrm{H}_{\beta}(\mathrm{OH})\left(\mathrm{OCH}_{3}\right)^{* * * *}+2^{*} \rightarrow \mathrm{C}_{6} \mathrm{H}_{4} \mathrm{H}_{\beta}(\mathrm{OH})\left(\mathrm{OCH}_{2}\right)^{* * * * *+\mathrm{H}^{*}}$ & $\mathrm{~K}_{8}$ & $1.35 \times 10^{1}$ & $9.38 \times 10^{0}$ & $7.00 \times 10^{0}$ & $5.52 \times 10^{0}$ \\
\hline & $\Delta \mathrm{E}_{8}=-0.16 \mathrm{eV}, \mathrm{E}_{8}^{\dagger}=0.88 \mathrm{eV}$ & $\mathrm{k}_{8}^{+}, \mathrm{s}^{-1}$ & $1.43 \times 10^{3}$ & $1.21 \times 10^{4}$ & $7.14 \times 10^{4}$ & $3.19 \times 10^{5}$ \\
\hline \multirow[t]{2}{*}{9} & $\mathrm{C}_{6} \mathrm{H}_{4} \mathrm{H}_{\beta}(\mathrm{OH})\left(\mathrm{OCH}_{3}\right)^{* * * *}+* \rightarrow \mathrm{C}_{6} \mathrm{H}_{5} \mathrm{OH}^{* * * *}+\mathrm{CH}_{3} \mathrm{O}^{*}$ & $\mathrm{~K}_{9}$ & $1.05 \times 10^{11}$ & $1.20 \times 10^{10}$ & $2.02 \times 10^{9}$ & $4.54 \times 10^{8}$ \\
\hline & $\Delta \mathrm{E}_{9}=-0.97 \mathrm{eV}, \mathrm{E}_{9}^{\dagger}=0.76 \mathrm{eV}$ & $\mathrm{k}_{9}{ }^{+}, \mathrm{s}^{-1}$ & $1.08 \times 10^{5}$ & $7.33 \times 10^{5}$ & $3.57 \times 10^{6}$ & $1.36 \times 10^{7}$ \\
\hline \multirow[t]{2}{*}{10} & $\mathrm{C}_{6} \mathrm{H}_{4} \mathrm{H}_{\alpha}(\mathrm{OH})\left(\mathrm{OCH}_{3}\right)^{* * * *}+* \rightarrow \mathrm{C}_{6} \mathrm{H}_{5} \mathrm{OCH}_{3} * * * *+\mathrm{OH}^{*}$ & $\mathrm{~K}_{10}$ & $5.08 \times 10^{9}$ & $7.16 \times 10^{8}$ & $1.43 \times 10^{8}$ & $3.73 \times 10^{7}$ \\
\hline & $\Delta \mathrm{E}_{10}=-0.88 \mathrm{eV}, \mathrm{E}_{10}^{\dagger}=0.58 \mathrm{eV}$ & $\mathrm{k}_{10}{ }^{+}, \mathrm{s}^{-1}$ & $1.47 \times 10^{7}$ & $6.52 \times 10^{7}$ & $2.24 \times 10^{8}$ & $6.36 \times 10^{8}$ \\
\hline \multirow[t]{2}{*}{11} & $\mathrm{C}_{6} \mathrm{H}_{4} \mathrm{OCH}_{3} * * * *+\mathrm{H}^{*} \rightarrow \mathrm{C}_{6} \mathrm{H}_{5} \mathrm{OCH}_{3} * * * *+$ & $\mathrm{K}_{11}$ & $1.07 \times 10^{2}$ & $6.94 \times 10^{1}$ & $4.81 \times 10^{1}$ & $3.52 \times 10^{1}$ \\
\hline & $\Delta \mathrm{E}_{11}=-0.18 \mathrm{eV}, \mathrm{E}_{11}^{\dagger}=0.67 \mathrm{eV}$ & $\mathrm{k}_{11}{ }^{+}, \mathrm{s}^{-1}$ & $1.15 \times 10^{6}$ & $6.09 \times 10^{6}$ & $2.42 \times 10^{7}$ & $7.71 \times 10^{7}$ \\
\hline \multirow[t]{2}{*}{12} & $\mathrm{C}_{6} \mathrm{H}_{4} \mathrm{OH}^{* * * *}+\mathrm{H}^{*} \rightarrow \mathrm{C}_{6} \mathrm{H}_{5} \mathrm{OH}^{* * * *}+*$ & $\mathrm{~K}_{12}$ & $8.83 \times 10^{1}$ & $5.81 \times 10^{1}$ & $4.08 \times 10^{1}$ & $3.02 \times 10^{1}$ \\
\hline & $\Delta \mathrm{E}_{12}=-0.17 \mathrm{eV}, \mathrm{E}_{12}^{\dagger}=0.60 \mathrm{eV}$ & $\mathrm{k}_{12}{ }^{+}, \mathrm{s}^{-1}$ & $7.84 \times 10^{6}$ & $3.56 \times 10^{7}$ & $1.25 \times 10^{8}$ & $3.58 \times 10^{8}$ \\
\hline \multirow[t]{2}{*}{13} & $\mathrm{C}_{6} \mathrm{H}_{4}(\mathrm{OH})\left(\mathrm{OCH}_{2}\right)^{* * * * * *}+* \rightarrow \mathrm{C}_{6} \mathrm{H}_{4}(\mathrm{OH})^{* * * *}+\mathrm{CH}_{2} \mathrm{O}^{* *}$ & $\mathrm{~K}_{13}$ & $4.03 \times 10^{2}$ & $2.54 \times 10^{2}$ & $1.74 \times 10^{2}$ & $1.27 \times 10^{2}$ \\
\hline & $\Delta \mathrm{E}_{13}=-0.22 \mathrm{eV}, \mathrm{E}_{13}^{\dagger}=1.22 \mathrm{eV}$ & $\mathrm{k}_{13}{ }^{+}, \mathrm{s}^{-1}$ & $4.90 \times 10^{-1}$ & $9.48 \times 10^{0}$ & $1.10 \times 10^{2}$ & $8.66 \times 10^{2}$ \\
\hline \multirow[t]{2}{*}{14} & $\mathrm{C}_{6} \mathrm{H}_{4}(\mathrm{OH})\left(\mathrm{OCH}_{2}\right)^{* * * * * *}+* \rightarrow \mathrm{C}_{6} \mathrm{H}_{4}(\mathrm{O})\left(\mathrm{OCH}_{2}\right)^{* * * * *}+\mathrm{H}^{*}$ & $\mathrm{~K}_{14}$ & $3.89 \times 10^{7}$ & $6.24 \times 10^{6}$ & $1.38 \times 10^{6}$ & $3.90 \times 10^{5}$ \\
\hline & $\Delta \mathrm{E}_{14}=-0.76 \mathrm{eV}, \mathrm{E}_{14}^{\dagger}=0.28 \mathrm{eV}$ & $\mathrm{k}_{14}{ }^{+}, \mathrm{s}^{-1}$ & $4.42 \times 10^{9}$ & $8.96 \times 10^{9}$ & $1.62 \times 10^{10}$ & $2.66 \times 10^{10}$ \\
\hline \multirow[t]{2}{*}{15} & $\mathrm{C}_{6} \mathrm{H}_{4}(\mathrm{OH})\left(\mathrm{OCH}_{2}\right)^{* * * * *}+* \rightarrow \mathrm{C}_{6} \mathrm{H}_{4}(\mathrm{OH})(\mathrm{OCH})^{* * * * *}+\mathrm{H}^{*}$ & $\mathrm{~K}_{15}$ & $4.79 \times 10^{5}$ & $1.33 \times 10^{5}$ & $4.65 \times 10^{4}$ & $1.93 \times 10^{4}$ \\
\hline & $\Delta \mathrm{E}_{15}=-0.55 \mathrm{eV}, \mathrm{E}_{15}{ }^{\dagger}=0.01 \mathrm{eV}$ & $\mathrm{k}_{15}{ }^{+}, \mathrm{s}^{-1}$ & $4.84 \times 10^{12}$ & $5.32 \times 10^{12}$ & $5.79 \times 10^{12}$ & $6.25 \times 10^{12}$ \\
\hline \multirow[t]{2}{*}{16} & $\mathrm{C}_{6} \mathrm{H}_{4}(\mathrm{OH})\left(\mathrm{OCH}_{2}\right)^{* * * * *} \rightarrow \mathrm{C}_{6} \mathrm{H}_{4}(\mathrm{OH})(\mathrm{O})^{* * * * *}+\mathrm{CH}_{2} *$ & $\mathrm{~K}_{16}$ & $2.47 \times 10^{13}$ & $1.39 \times 10^{12}$ & $1.31 \times 10^{11}$ & $1.80 \times 10^{10}$ \\
\hline & $\Delta \mathrm{E}_{16}=-1.25 \mathrm{eV}, \mathrm{E}_{16}^{\dagger}=0.45 \mathrm{eV}$ & $\mathrm{k}_{16}{ }^{+}, \mathrm{s}^{-1}$ & $1.39 \times 10^{8}$ & $4.33 \times 10^{8}$ & $1.11 \times 10^{9}$ & $2.47 \times 10^{9}$ \\
\hline \multirow[t]{2}{*}{17} & $\mathrm{C}_{6} \mathrm{H}_{4}(\mathrm{OH})(\mathrm{O}) * * * *+\mathrm{H}^{*} \rightarrow \mathrm{C}_{6} \mathrm{H}_{4}(\mathrm{OH})_{2} * * * * *$ & $\mathrm{~K}_{17}$ & $5.39 \times 10^{-8}$ & $3.41 \times 10^{-8}$ & $1.56 \times 10^{-7}$ & $5.57 \times 10^{-7}$ \\
\hline & $\Delta \mathrm{E}_{17}=0.78 \mathrm{eV}, \mathrm{E}_{17}^{\dagger}=1.06 \mathrm{eV}$ & $\mathrm{k}_{17}^{+}, \mathrm{s}^{-1}$ & $8.46 \times 10^{1}$ & $1.15 \times 10^{3}$ & $9.96 \times 10^{3}$ & $6.12 \times 10^{4}$ \\
\hline \multirow[t]{2}{*}{18} & $\mathrm{C}_{6} \mathrm{H}_{4}(\mathrm{OH})(\mathrm{O})^{* * * *}+\mathrm{H}^{*} \rightarrow \mathrm{C}_{6} \mathrm{H}_{4} \mathrm{H}_{\alpha}(\mathrm{OH})(\mathrm{O})^{* * * *}+*$ & $\mathrm{~K}_{18}$ & $3.05 \times 10^{-10}$ & $2.21 \times 10^{-9}$ & $1.12 \times 10^{-8}$ & $4.39 \times 10^{-8}$ \\
\hline & $\Delta \mathrm{E}_{18}=0.87 \mathrm{eV}, \mathrm{E}_{18}^{\dagger}=1.42 \mathrm{eV}$ & $\mathrm{k}_{18}^{+}, \mathrm{s}^{-1}$ & $7.62 \times 10^{-3}$ & $2.35 \times 10^{-1}$ & $3.56 \times 10^{0}$ & $4.33 \times 10^{1}$ \\
\hline \multirow[t]{2}{*}{19} & $\mathrm{C}_{6} \mathrm{H}_{4}(\mathrm{OH})(\mathrm{O})^{* * * * *}+* \rightarrow \mathrm{C}_{6} \mathrm{H}_{4} \mathrm{O}^{* * * *}+\mathrm{OH}^{*}$ & $\mathrm{~K}_{19}$ & $3.11 \times 10^{-6}$ & $1.13 \times 10^{-5}$ & $3.32 \times 10^{-5}$ & $8.23 \times 10^{-5}$ \\
\hline & $\Delta \mathrm{E}_{19}=0.53 \mathrm{eV}, \mathrm{E}_{19}^{\dagger}=1.14 \mathrm{eV}$ & $\mathrm{k}_{19}{ }^{+}, \mathrm{s}^{-1}$ & $3.59 \times 10^{0}$ & $5.57 \times 10^{1}$ & $5.40 \times 10^{2}$ & $3.65 \times 10^{3}$ \\
\hline
\end{tabular}


Table 4. (continued)

\begin{tabular}{|c|c|c|c|c|c|c|}
\hline \multirow[b]{2}{*}{ Step } & \multirow[b]{2}{*}{ Reaction } & \multirow[b]{2}{*}{ constant } & \multicolumn{4}{|c|}{$\mathrm{T}(\mathrm{K})$} \\
\hline & & & 473 & 523 & 573 & 623 \\
\hline \multirow[t]{2}{*}{20} & $\mathrm{C}_{6} \mathrm{H}_{4}(\mathrm{O})\left(\mathrm{OCH}_{3}\right)^{* * * *}+* \rightarrow \mathrm{C}_{6} \mathrm{H}_{4} \mathrm{O}^{* * * *}+\mathrm{CH}_{3} \mathrm{O}^{*}$ & $\mathrm{~K}_{20}$ & $7.15 \times 10^{-3}$ & $1.40 \times 10^{-2}$ & $2.45 \times 10^{-2}$ & $3.93 \times 10^{-2}$ \\
\hline & $\Delta \mathrm{E}_{20}=0.26 \mathrm{eV}, \mathrm{E}_{20}^{\dagger}=1.08 \mathrm{eV}$ & $\mathrm{K}_{20}{ }^{+}, \mathrm{s}^{-1}$ & $3.00 \times 10^{1}$ & $4.18 \times 10^{2}$ & $3.71 \times 10^{3}$ & $2.33 \times 10^{4}$ \\
\hline \multirow[t]{2}{*}{21} & $\mathrm{C}_{6} \mathrm{H}_{4}(\mathrm{O})\left(\mathrm{OCH}_{3}\right)^{* * * *}+2 * \rightarrow \mathrm{C}_{6} \mathrm{H}_{4}(\mathrm{O})\left(\mathrm{OCH}_{2}\right)^{* * * * *+\mathrm{H}^{*}}$ & $\mathrm{~K}_{21}$ & $1.24 \times 10^{3}$ & $2.94 \times 10^{3}$ & $5.96 \times 10^{2}$ & $1.08 \times 10^{2}$ \\
\hline & $\Delta \mathrm{E}_{21}=-0.38 \mathrm{eV}, \mathrm{E}_{21}^{\dagger}=0.49 \mathrm{eV}$ & $\mathrm{k}_{21}^{+}, \mathrm{s}^{-1}$ & $1.36 \times 10^{1}$ & $1.99 \times 10^{2}$ & $1.83 \times 10^{3}$ & $1.18 \times 10^{4}$ \\
\hline \multirow[t]{2}{*}{22} & $\mathrm{C}_{6} \mathrm{H}_{4} \mathrm{H}_{\beta}(\mathrm{OH})\left(\mathrm{OCH}_{2}\right)^{* * * * *} \rightarrow \mathrm{C}_{6} \mathrm{H}_{4} \mathrm{H}_{\beta}(\mathrm{OH})(\mathrm{O})^{* * * *}+\mathrm{CH}_{2} *$ & $\mathrm{~K}_{22}$ & $1.21 \times 10^{9}$ & $1.77 \times 10^{8}$ & $3.63 \times 10^{7}$ & $9.66 \times 10^{6}$ \\
\hline & $\Delta \mathrm{E}_{22}=-0.85 \mathrm{eV}, \mathrm{E}_{22}^{\dagger}=0.37 \mathrm{eV}$ & $\mathrm{k}_{22}{ }^{+}, \mathrm{s}^{-1}$ & $1.24 \times 10^{9}$ & $3.21 \times 10^{9}$ & $7.04 \times 10^{9}$ & $1.37 \times 10^{10}$ \\
\hline \multirow[t]{2}{*}{23} & $\mathrm{C}_{6} \mathrm{H}_{5} \mathrm{OCH}_{3} * * * *+* \mathrm{C}_{6} \mathrm{H}_{5} \mathrm{OCH}_{2} * * * *+\mathrm{H}^{*}$ & $\mathrm{~K}_{23}$ & $1.72 \times 10^{3}$ & $6.76 \times 10^{2}$ & $3.14 \times 10^{2}$ & $1.66 \times 10^{2}$ \\
\hline & $\Delta \mathrm{E}_{23}=-0.38 \mathrm{eV}, \mathrm{E}_{23}^{\dagger}=0.44 \mathrm{eV}$ & $\mathrm{k}_{23}{ }^{+}, \mathrm{s}^{-1}$ & $7.26 \times 10^{7}$ & $2.19 \times 10^{8}$ & $5.50 \times 10^{8}$ & $1.20 \times 10^{9}$ \\
\hline \multirow[t]{2}{*}{24} & $\mathrm{C}_{6} \mathrm{H}_{4}(\mathrm{OH})(\mathrm{OCH})^{* * * * * *}+* \rightarrow \mathrm{C}_{6} \mathrm{H}_{4}(\mathrm{OH})^{* * * * *}+\mathrm{CHO}^{* *}$ & $\mathrm{~K}_{24}$ & $5.59 \times 10^{2}$ & $3.67 \times 10^{2}$ & $2.60 \times 10^{2}$ & $1.96 \times 10^{2}$ \\
\hline & $\Delta \mathrm{E}_{24}=-0.22 \mathrm{eV}, \mathrm{E}_{24}^{\dagger}=1.03 \mathrm{eV}$ & $\mathrm{k}_{24}{ }^{+}, \mathrm{s}^{-1}$ & $2.32 \times 10^{2}$ & $2.89 \times 10^{3}$ & $2.34 \times 10^{4}$ & $1.36 \times 10^{5}$ \\
\hline \multirow[t]{2}{*}{25} & $\mathrm{C}_{6} \mathrm{H}_{4}(\mathrm{OH})(\mathrm{OCH})^{* * * * *} \rightarrow \mathrm{C}_{6} \mathrm{H}_{4}(\mathrm{OH})(\mathrm{O})^{* * * *}+\mathrm{CH}^{*}$ & $\mathrm{~K}_{25}$ & $6.83 \times 10^{13}$ & $3.46 \times 10^{12}$ & $2.96 \times 10^{11}$ & $3.77 \times 10^{10}$ \\
\hline & $\Delta \mathrm{E}_{25}=-1.29 \mathrm{eV}, \mathrm{E}_{25}^{\dagger}=0.31 \mathrm{eV}$ & $\mathrm{k}_{25}{ }^{+}, \mathrm{s}^{-1}$ & $3.83 \times 10^{9}$ & $8.46 \times 10^{9}$ & $1.63 \times 10^{10}$ & $2.84 \times 10^{10}$ \\
\hline \multirow[t]{2}{*}{26} & $\mathrm{C}_{6} \mathrm{H}_{4}(\mathrm{OH})_{2}^{* * * *+*} \rightarrow \mathrm{C}_{6} \mathrm{H}_{4}(\mathrm{OH})^{* * * *}+\mathrm{OH}^{*}$ & $\mathrm{~K}_{26}$ & $6.89 \times 10^{1}$ & $5.27 \times 10^{1}$ & $4.26 \times 10^{1}$ & $3.58 \times 10^{1}$ \\
\hline & $\Delta \mathrm{E}_{26}=-0.15 \mathrm{eV}, \mathrm{E}_{26}{ }^{\dagger}=1.16 \mathrm{eV}$ & $\mathrm{k}_{26}{ }^{+}, \mathrm{s}^{-1}$ & $3.96 \times 10^{0}$ & $6.52 \times 10^{1}$ & $6.62 \times 10^{2}$ & $4.66 \times 10^{3}$ \\
\hline \multirow[t]{2}{*}{27} & $\mathrm{C}_{6} \mathrm{H}_{4}(\mathrm{OH})_{2} * * * *+\mathrm{H}^{*} \rightarrow \mathrm{C}_{6} \mathrm{H}_{5}(\mathrm{OH})_{2} * * * * *$ & $\mathrm{~K}_{27}$ & $3.33 \times 10^{-6}$ & $1.06 \times 10^{-5}$ & $2.72 \times 10^{-5}$ & $5.98 \times 10^{-5}$ \\
\hline & $\Delta \mathrm{E}_{27}=0.51 \mathrm{eV}, \mathrm{E}_{27}^{\dagger}=1.16 \mathrm{eV}$ & $\mathrm{k}_{27}^{+}, \mathrm{s}^{-1}$ & $3.90 \times 10^{0}$ & $6.40 \times 10^{1}$ & $6.46 \times 10^{2}$ & $4.51 \times 10^{3}$ \\
\hline \multirow[t]{2}{*}{28} & $\mathrm{C}_{6} \mathrm{H}_{4} \mathrm{H}_{\alpha}(\mathrm{OH})(\mathrm{O})^{* * * *}+* \rightarrow \mathrm{C}_{6} \mathrm{H}_{5} \mathrm{O}^{* * * *}+\mathrm{OH}^{*}$ & $\mathrm{~K}_{28}$ & $1.13 \times 10^{1}$ & $1.08 \times 10^{1}$ & $1.06 \times 10^{1}$ & $1.04 \times 10^{1}$ \\
\hline & $\Delta \mathrm{E}_{28}=-0.06 \mathrm{eV}, \mathrm{E}_{28}^{\dagger}=0.81 \mathrm{eV}$ & $\mathrm{k}_{28}{ }^{+}, \mathrm{s}^{-1}$ & $5.76 \times 10^{4}$ & $4.42 \times 10^{5}$ & $2.40 \times 10^{6}$ & $1.00 \times 10^{7}$ \\
\hline \multirow[t]{2}{*}{29} & $\mathrm{C}_{6} \mathrm{H}_{4} \mathrm{O} * * * *+\mathrm{H}^{*} \rightarrow \mathrm{C}_{6} \mathrm{H}_{5} \mathrm{O}^{* * * * *}+*$ & $\mathrm{~K}_{29}$ & $5.39 \times 10^{9}$ & $6.29 \times 10^{8}$ & $1.06 \times 10^{8}$ & $2.37 \times 10^{7}$ \\
\hline & $\Delta \mathrm{E}_{29}=-0.91 \mathrm{eV}, \mathrm{E}_{29}^{\dagger}=0.54 \mathrm{eV}$ & $\mathrm{k}_{29}{ }^{+}, \mathrm{s}^{-1}$ & $1.72 \times 10^{7}$ & $6.77 \times 10^{7}$ & $2.11 \times 10^{8}$ & $5.50 \times 10^{8}$ \\
\hline \multirow[t]{2}{*}{30} & $\mathrm{C}_{6} \mathrm{H}_{4}(\mathrm{O})\left(\mathrm{OCH}_{2}\right)^{* * * * * *}+* \rightarrow \mathrm{C}_{6} \mathrm{H}_{4} \mathrm{O}^{* * * *}+\mathrm{CH}_{2} \mathrm{O}^{*}$ & $\mathrm{~K}_{30}$ & $2.49 \times 10^{-8}$ & $1.26 \times 10^{-7}$ & $4.78 \times 10^{-7}$ & $1.46 \times 10^{-6}$ \\
\hline & $\Delta \mathrm{E}_{30}=0.70 \mathrm{eV}, \mathrm{E}_{30}^{\dagger}=1.29 \mathrm{eV}$ & $\mathrm{k}_{30}{ }^{+}, \mathrm{s}^{-1}$ & $3.42 \times 10^{-2}$ & $7.20 \times 10^{-1}$ & $8.91 \times 10^{0}$ & $7.35 \times 10^{1}$ \\
\hline \multirow[t]{2}{*}{31} & $\mathrm{C}_{6} \mathrm{H}_{4}(\mathrm{O})\left(\mathrm{OCH}_{2}\right)^{* * * * *}+* \rightarrow \mathrm{C}_{6} \mathrm{H}_{4} \mathrm{O}_{2} * * * * *+\mathrm{CH}_{2} *$ & $\mathrm{~K}_{31}$ & $3.46 \times 10^{6}$ & $7.17 \times 10^{5}$ & $1.96 \times 10^{5}$ & $6.60 \times 10^{4}$ \\
\hline & $\Delta \mathrm{E}_{31}=-0.67 \mathrm{eV}, \mathrm{E}_{31}^{\dagger}=0.79 \mathrm{eV}$ & $\mathrm{k}_{31}{ }^{+}, \mathrm{s}^{-1}$ & $1.08 \times 10^{4}$ & $6.98 \times 10^{4}$ & $3.27 \times 10^{5}$ & $1.19 \times 10^{6}$ \\
\hline \multirow[t]{2}{*}{32} & $\mathrm{C}_{6} \mathrm{H}_{4}(\mathrm{O})\left(\mathrm{OCH}_{2}\right)^{* * * * *}+* \rightarrow \mathrm{C}_{6} \mathrm{H}_{4}(\mathrm{O})(\mathrm{OCH})^{* * * * *}+\mathrm{H}^{*}$ & $\mathrm{~K}_{32}$ & $2.82 \times 10^{5}$ & $8.44 \times 10^{4}$ & $3.14 \times 10^{4}$ & $1.38 \times 10^{4}$ \\
\hline & $\Delta \mathrm{E}_{32}=-0.52 \mathrm{eV}, \mathrm{E}_{32}^{\dagger}=0.01 \mathrm{eV}$ & $\mathrm{k}_{32}{ }^{+}, \mathrm{s}^{-1}$ & $5.39 \times 10^{12}$ & $6.04 \times 10^{12}$ & $6.68 \times 10^{12}$ & $7.31 \times 10^{12}$ \\
\hline \multirow[t]{2}{*}{33} & $\mathrm{C}_{6} \mathrm{H}_{4}(\mathrm{O})(\mathrm{OCH})^{* * * * * *+*} \rightarrow \mathrm{C}_{6} \mathrm{H}_{4} \mathrm{O}_{2} * * * * *+\mathrm{CH}^{*}$ & $\mathrm{~K}_{33}$ & $5.67 \times 10^{10}$ & $5.73 \times 10^{9}$ & $8.67 \times 10^{8}$ & $1.79 \times 10^{8}$ \\
\hline & $\Delta \mathrm{E}_{33}=-1.00 \mathrm{eV}, \mathrm{E}_{33}^{\dagger}=0.47 \mathrm{eV}$ & $\mathrm{k}_{33}{ }^{+}, \mathrm{s}^{-1}$ & $1.56 \times 10^{8}$ & $5.16 \times 10^{8}$ & $1.40 \times 10^{9}$ & $3.23 \times 10^{9}$ \\
\hline \multirow[t]{2}{*}{34} & $\mathrm{C}_{6} \mathrm{H}_{4}(\mathrm{O})(\mathrm{OCH})^{* * * * *}+* \rightarrow \mathrm{C}_{6} \mathrm{H}_{4}(\mathrm{O})(\mathrm{OC})^{* * * * *}+\mathrm{H}^{*}$ & $\mathrm{~K}_{34}$ & $5.36 \times 10^{3}$ & $2.35 \times 10^{3}$ & $1.19 \times 10^{3}$ & $6.79 \times 10^{2}$ \\
\hline & $\Delta \mathrm{E}_{34}=-0.35 \mathrm{eV}, \mathrm{E}_{34}^{\dagger}=0.39 \mathrm{eV}$ & $\mathrm{k}_{34}{ }^{+}, \mathrm{s}^{-1}$ & $7.76 \times 10^{8}$ & $2.11 \times 10^{9}$ & $4.83 \times 10^{9}$ & $9.75 \times 10^{9}$ \\
\hline \multirow[t]{2}{*}{35} & $\mathrm{C}_{6} \mathrm{H}_{4} \mathrm{H}_{\beta}(\mathrm{OH})(\mathrm{O})^{* * * * * *}+\mathrm{H}^{*} \rightarrow \mathrm{C}_{6} \mathrm{H}_{5}(\mathrm{OH})_{2} * * * * *+*$ & $\mathrm{~K}_{35}$ & $6.34 \times 10^{-3}$ & $1.09 \times 10^{-2}$ & $1.71 \times 10^{-2}$ & $2.47 \times 10^{-2}$ \\
\hline & $\Delta \mathrm{E}_{35}=0.23 \mathrm{eV}, \mathrm{E}_{35}{ }^{\dagger}=0.90 \mathrm{eV}$ & $\mathrm{k}_{35}{ }^{+}, \mathrm{s}^{-1}$ & $3.25 \times 10^{3}$ & $3.00 \times 10^{4}$ & $1.89 \times 10^{5}$ & $8.90 \times 10^{5}$ \\
\hline \multirow[t]{2}{*}{36} & $\mathrm{C}_{6} \mathrm{H}_{5} \mathrm{OCH}_{2} * * * *+* \rightarrow \mathrm{C}_{6} \mathrm{H}_{5} \mathrm{O}^{* * * * *}+\mathrm{CH}_{2} *$ & $\mathrm{~K}_{36}$ & $9.70 \times 10^{13}$ & $5.14 \times 10^{12}$ & $4.59 \times 10^{11}$ & $6.09 \times 10^{10}$ \\
\hline & $\Delta \mathrm{E}_{36}=-1.29 \mathrm{eV}, \mathrm{E}_{36}{ }^{\dagger}=0.12 \mathrm{eV}$ & $\mathrm{k}_{36}{ }^{+}, \mathrm{s}^{-1}$ & $4.50 \times 10^{11}$ & $6.56 \times 10^{11}$ & $9.01 \times 10^{11}$ & $1.18 \times 10^{12}$ \\
\hline \multirow[t]{2}{*}{37} & $\mathrm{C}_{6} \mathrm{H}_{5} \mathrm{O} * * * *+\mathrm{H}^{*} \rightarrow \mathrm{C}_{6} \mathrm{H}_{5} \mathrm{OH}^{* * * *}+*$ & $\mathrm{~K}_{37}$ & $8.91 \times 10^{-10}$ & $7.18 \times 10^{-9}$ & $4.01 \times 10^{-8}$ & $1.70 \times 10^{-7}$ \\
\hline & $\Delta \mathrm{E}_{37}=0.88 \mathrm{eV}, \mathrm{E}_{37}^{\dagger}=1.05 \mathrm{eV}$ & $\mathrm{k}_{37}^{+}, \mathrm{s}^{-1}$ & $7.19 \times 10^{1}$ & $9.24 \times 10^{2}$ & $7.63 \times 10^{3}$ & $4.51 \times 10^{4}$ \\
\hline \multirow[t]{2}{*}{38} & $\mathrm{C}_{6} \mathrm{H}_{5} \mathrm{OH}^{* * * *}+* \rightarrow \mathrm{C}_{6} \mathrm{H}_{5} * * * *+\mathrm{OH}^{*}$ & $\mathrm{~K}_{38}$ & $1.87 \times 10^{1}$ & $1.47 \times 10^{1}$ & $1.20 \times 10^{1}$ & $1.03 \times 10^{1}$ \\
\hline & $\Delta \mathrm{E}_{38}=-0.13 \mathrm{eV}, \mathrm{E}_{38}^{\dagger}=1.15 \mathrm{eV}$ & $\mathrm{k}_{38}{ }^{+}, \mathrm{s}^{-1}$ & $3.85 \times 10^{0}$ & $6.26 \times 10^{1}$ & $6.30 \times 10^{2}$ & $4.40 \times 10^{3}$ \\
\hline \multirow[t]{2}{*}{39} & $\mathrm{C}_{6} \mathrm{H}_{5} \mathrm{OH}^{* * * *}+\mathrm{H}^{*} \rightarrow \mathrm{C}_{6} \mathrm{H}_{6} \mathrm{OH}^{* * * * *}+*$ & $\mathrm{~K}_{39}$ & $9.44 \times 10^{-7}$ & $3.10 \times 10^{-6}$ & $8.20 \times 10^{-6}$ & $1.85 \times 10^{-5}$ \\
\hline & $\Delta \mathrm{E}_{39}=0.53 \mathrm{eV}, \mathrm{E}_{39}^{\dagger}=1.25 \mathrm{eV}$ & $\mathrm{k}_{39}{ }^{+}, \mathrm{s}^{-1}$ & $4.39 \times 10^{-1}$ & $8.92 \times 10^{0}$ & $1.08 \times 10^{2}$ & $8.69 \times 10^{2}$ \\
\hline
\end{tabular}


Table 4. (continued)

\begin{tabular}{|c|c|c|c|c|c|c|}
\hline & & & \multicolumn{4}{|c|}{$\mathrm{T}(\mathrm{K})$} \\
\hline Step & Reaction & constant & 473 & 523 & 573 & 623 \\
\hline \multirow[t]{2}{*}{40} & $\mathrm{C}_{6} \mathrm{H}_{5}(\mathrm{OH})_{2} * * * *+* \rightarrow \mathrm{C}_{6} \mathrm{H}_{5} \mathrm{OH}^{* * * * *}+\mathrm{OH}^{*}$ & $\mathrm{~K}_{40}$ & $8.59 \times 10^{8}$ & $1.47 \times 10^{8}$ & $3.43 \times 10^{7}$ & $1.02 \times 10^{7}$ \\
\hline & $\Delta \mathrm{E}_{40}=-0.80 \mathrm{eV}, \mathrm{E}_{40}^{\dagger}=0.63 \mathrm{eV}$ & $\mathrm{k}_{40}{ }^{+}, \mathrm{s}^{-1}$ & $4.99 \times 10^{6}$ & $2.48 \times 10^{7}$ & $9.36 \times 10^{7}$ & $2.87 \times 10^{8}$ \\
\hline \multirow[t]{2}{*}{41} & $\mathrm{C}_{6} \mathrm{H}_{4} \mathrm{O}_{2} * * * * *+\mathrm{H}^{*} \rightarrow \mathrm{C}_{6} \mathrm{H}_{4}(\mathrm{OH})(\mathrm{O})^{* * * * *}+2^{*}$ & $\mathrm{~K}_{41}$ & $5.26 \times 10^{-5}$ & $1.53 \times 10^{-4}$ & $3.66 \times 10^{-4}$ & $7.60 \times 10^{-5}$ \\
\hline & $\Delta \mathrm{E}_{41}=0.44 \mathrm{eV}, \mathrm{E}_{41}^{\dagger}=0.96 \mathrm{eV}$ & $\mathrm{k}_{41}^{+}, \mathrm{s}^{-1}$ & $1.26 \times 10^{3}$ & $1.34 \times 10^{4}$ & $9.54 \times 10^{4}$ & $4.96 \times 10^{5}$ \\
\hline \multirow[t]{2}{*}{42} & $\mathrm{C}_{6} \mathrm{H}_{4}(\mathrm{O})(\mathrm{OC})^{* * * * *} \rightarrow \mathrm{C}_{6} \mathrm{H}_{4} \mathrm{O}^{* * * * *}+\mathrm{CO}^{*}$ & $\mathrm{~K}_{42}$ & $2.06 \times 10^{5}$ & $8.48 \times 10^{4}$ & $4.09 \times 10^{4}$ & $2.22 \times 10^{4}$ \\
\hline & $\Delta \mathrm{E}_{42}=-0.41 \mathrm{eV}, \mathrm{E}_{42}^{\dagger}=0.68 \mathrm{eV}$ & $\mathrm{k}_{42}{ }^{+}, \mathrm{s}^{-1}$ & $9.47 \times 10^{5}$ & $5.19 \times 10^{6}$ & $2.13 \times 10^{7}$ & $6.97 \times 10^{7}$ \\
\hline \multirow[t]{2}{*}{43} & $\mathrm{C}_{6} \mathrm{H}_{5} * * * *+\mathrm{H}^{*} \rightarrow \mathrm{C}_{6} \mathrm{H}_{6} * * *+2 *$ & $\mathrm{~K}_{43}$ & $1.02 \times 10^{2}$ & $6.83 \times 10^{1}$ & $4.89 \times 10^{1}$ & $3.68 \times 10^{1}$ \\
\hline & $\Delta \mathrm{E}_{43}=-0.17 \mathrm{eV}, \mathrm{E}_{43}^{\dagger}=0.55 \mathrm{eV}$ & $\mathrm{k}_{43}{ }^{+}, \mathrm{s}^{-1}$ & $2.02 \times 10^{7}$ & $8.23 \times 10^{7}$ & $2.64 \times 10^{8}$ & $7.02 \times 10^{8}$ \\
\hline \multirow[t]{2}{*}{44} & $\mathrm{C}_{6} \mathrm{H}_{6} \mathrm{OH}^{* * * *} \rightarrow \mathrm{C}_{6} \mathrm{H}_{6} * * *+\mathrm{OH}^{*}$ & $\mathrm{~K}_{44}$ & $2.01 \times 10^{9}$ & $3.23 \times 10^{8}$ & $7.19 \times 10^{7}$ & $2.05 \times 10^{7}$ \\
\hline & $\Delta \mathrm{E}_{44}=-0.83 \mathrm{eV}, \mathrm{E}_{44}^{\dagger}=0.56 \mathrm{eV}$ & $\mathrm{k}_{44^{+}}, \mathrm{s}^{-1}$ & $2.38 \times 10^{7}$ & $1.01 \times 10^{8}$ & $3.37 \times 10^{8}$ & $9.29 \times 10^{8}$ \\
\hline \multirow[t]{2}{*}{45} & $\mathrm{CH}^{*}+\mathrm{H}^{*} \rightarrow \mathrm{CH}_{2}^{*}+*$ & $\mathrm{~K}_{45}$ & $7.55 \times 10^{-7}$ & $3.03 \times 10^{-6}$ & $9.50 \times 10^{-6}$ & $2.47 \times 10^{-5}$ \\
\hline & $\Delta \mathrm{E}_{45}=0.59 \mathrm{eV}, \mathrm{E}_{45}^{\dagger}=0.62 \mathrm{eV}$ & $\mathrm{k}_{45}{ }^{+}, \mathrm{s}^{-1}$ & $2.36 \times 10^{6}$ & $1.09 \times 10^{7}$ & $3.85 \times 10^{7}$ & $1.11 \times 10^{8}$ \\
\hline \multirow[t]{2}{*}{46} & $\mathrm{CH}_{2} *+\mathrm{H}^{*} \rightarrow \mathrm{CH}_{3}^{*}+*$ & $\mathrm{~K}_{46}$ & $1.03 \times 10^{-3}$ & $2.12 \times 10^{-3}$ & $3.81 \times 10^{-3}$ & $6.21 \times 10^{-3}$ \\
\hline & $\Delta \mathrm{E}_{46}=0.30 \mathrm{eV}, \mathrm{E}_{46}^{\dagger}=0.62 \mathrm{eV}$ & $\mathrm{k}_{46}^{+}, \mathrm{s}^{-1}$ & $2.30 \times 10^{6}$ & $1.07 \times 10^{7}$ & $3.78 \times 10^{7}$ & $1.09 \times 10^{8}$ \\
\hline \multirow[t]{2}{*}{47} & $\mathrm{CH}_{3}^{*}+\mathrm{H}^{*} \rightarrow \mathrm{CH}_{4}^{*}+*$ & $\mathrm{~K}_{47}$ & $1.36 \times 10^{-5}$ & $6.89 \times 10^{-5}$ & $2.61 \times 10^{-4}$ & $7.91 \times 10^{-4}$ \\
\hline & $\Delta \mathrm{E}_{47}=0.64 \mathrm{eV}, \mathrm{E}_{47}^{\dagger}=1.13 \mathrm{eV}$ & $\mathrm{k}_{47}^{+}, \mathrm{s}^{-1}$ & $5.88 \times 10^{1}$ & $9.50 \times 10^{2}$ & $9.43 \times 10^{3}$ & $6.48 \times 10^{4}$ \\
\hline \multirow[t]{2}{*}{48} & $\mathrm{OH}^{*}+\mathrm{H}^{*} \rightarrow \mathrm{H}_{2} \mathrm{O}^{*}+*$ & $\mathrm{~K}_{48}$ & $5.25 \times 10^{-6}$ & $2.15 \times 10^{-5}$ & $6.85 \times 10^{-5}$ & $1.81 \times 10^{-4}$ \\
\hline & $\Delta \mathrm{E}_{48}=0.57 \mathrm{eV}, \mathrm{E}_{48}^{\dagger}=1.18 \mathrm{eV}$ & $\mathrm{k}_{48}{ }^{+}, \mathrm{s}^{-1}$ & $8.57 \times 10^{0}$ & $1.53 \times 10^{2}$ & $1.67 \times 10^{3}$ & $1.24 \times 10^{4}$ \\
\hline \multirow[t]{2}{*}{49} & $\mathrm{CHO}^{* *}+\mathrm{H}^{*} \rightarrow \mathrm{CH}_{2} \mathrm{O}^{* *}+*$ & $\mathrm{~K}_{49}$ & $1.92 \times 10^{-6}$ & $6.39 \times 10^{-6}$ & $1.72 \times 10^{-5}$ & $3.92 \times 10^{-5}$ \\
\hline & $\Delta \mathrm{E}_{49}=0.52 \mathrm{eV}, \mathrm{E}_{49}{ }^{\dagger}=0.50 \mathrm{eV}$ & $\mathrm{k}_{49}{ }^{+}, \mathrm{s}^{-1}$ & $3.20 \times 10^{7}$ & $1.11 \times 10^{8}$ & $3.09 \times 10^{8}$ & $7.34 \times 10^{8}$ \\
\hline \multirow[t]{2}{*}{50} & $\mathrm{CH}_{2} \mathrm{O}^{* *}+\mathrm{H}^{*} \rightarrow \mathrm{CH}_{3} \mathrm{O}^{*}+2^{*}$ & $\mathrm{~K}_{50}$ & $2.74 \times 10^{-2}$ & $4.59 \times 10^{-2}$ & $6.98 \times 10^{-2}$ & $9.83 \times 10^{-2}$ \\
\hline & $\Delta \mathrm{E}_{50}=0.21 \mathrm{eV}, \mathrm{E}_{50}^{\dagger}=0.73 \mathrm{eV}$ & $\mathrm{k}_{50}{ }^{+}, \mathrm{s}^{-1}$ & $5.07 \times 10^{5}$ & $3.49 \times 10^{6}$ & $1.56 \times 10^{7}$ & $5.46 \times 10^{7}$ \\
\hline \multirow[t]{2}{*}{51} & $\mathrm{CH}_{3} \mathrm{O}^{*}+\mathrm{H}^{*} \rightarrow \mathrm{CH}_{3} \mathrm{OH}^{*}+*$ & $\mathrm{~K}_{51}$ & $1.65 \times 10^{-8}$ & $1.03 \times 10^{-7}$ & $4.63 \times 10^{-7}$ & $1.63 \times 10^{-6}$ \\
\hline & $\Delta \mathrm{E}_{51}=0.77 \mathrm{eV}, \mathrm{E}_{51}^{\dagger}=1.23 \mathrm{eV}$ & $\mathrm{k}_{51}{ }^{+}, \mathrm{s}^{-1}$ & $1.02 \times 10^{0}$ & $2.02 \times 10^{1}$ & $2.38 \times 10^{2}$ & $1.90 \times 10^{3}$ \\
\hline \multirow[t]{2}{*}{52} & $\mathrm{C}_{6} \mathrm{H}_{5} \mathrm{OCH}_{3} * * * * \rightarrow \mathrm{C}_{6} \mathrm{H}_{5} \mathrm{OCH}_{3}$ (gas) $+4 *$ & $\mathrm{~K}_{52}$ & $2.23 \times 10^{-11}$ & $3.13 \times 10^{-8}$ & $1.52 \times 10^{-5}$ & $3.27 \times 10^{-3}$ \\
\hline & $\Delta \mathrm{E}_{52}=2.54 \mathrm{eV}$ & $\mathrm{k}_{52}{ }^{+}, \mathrm{s}^{-1}$ & $1.64 \times 10^{-3}$ & $2.19 \times 10^{0}$ & $1.02 \times 10^{3}$ & $2.10 \times 10^{5}$ \\
\hline \multirow[t]{2}{*}{53} & $\mathrm{C}_{6} \mathrm{H}_{4}(\mathrm{OH})_{2} * * * * \mathrm{C}_{6} \mathrm{H}_{4}(\mathrm{OH})_{2}(\mathrm{gas})+4 *$ & $\mathrm{~K}_{53}$ & $2.49 \times 10^{-12}$ & $3.92 \times 10^{-9}$ & $2.07 \times 10^{-6}$ & $4.71 \times 10^{-4}$ \\
\hline & $\Delta \mathrm{E}_{53}=2.60 \mathrm{eV}$ & $\mathrm{k}_{53}{ }^{+}, \mathrm{s}^{-1}$ & $1.82 \times 10^{-4}$ & $2.73 \times 10^{-1}$ & $1.37 \times 10^{2}$ & $3.00 \times 10^{4}$ \\
\hline \multirow[t]{2}{*}{54} & $\mathrm{C}_{6} \mathrm{H}_{5} \mathrm{OH}^{* * * *} \rightarrow \mathrm{C}_{6} \mathrm{H}_{5} \mathrm{OH}($ gas $)+4 *$ & $\mathrm{~K}_{54}$ & $2.35 \times 10^{-12}$ & $2.49 \times 10^{-9}$ & $9.16 \times 10^{-7}$ & $1.55 \times 10^{-4}$ \\
\hline & $\Delta \mathrm{E}_{54}=2.51 \mathrm{eV}$ & $\mathrm{k}_{54}{ }^{+}, \mathrm{s}^{-1}$ & $1.86 \times 10^{-4}$ & $1.87 \times 10^{-1}$ & $6.58 \times 10^{1}$ & $1.06 \times 10^{4}$ \\
\hline \multirow[t]{2}{*}{55} & $\mathrm{C}_{6} \mathrm{H}_{6} * * * \rightarrow \mathrm{C}_{6} \mathrm{H}_{6}$ (gas) $+3 *$ & $\mathrm{~K}_{55}$ & $1.96 \times 10^{-13}$ & $1.43 \times 10^{-10}$ & $3.81 \times 10^{-8}$ & $4.74 \times 10^{-6}$ \\
\hline & $\Delta \mathrm{E}_{55}=2.42 \mathrm{eV}$ & $\mathrm{k}_{55}{ }^{+}, \mathrm{s}^{-1}$ & $1.70 \times 10^{-5}$ & $1.18 \times 10^{-2}$ & $3.00 \times 10^{0}$ & $3.59 \times 10^{2}$ \\
\hline \multirow[t]{2}{*}{56} & $\mathrm{CH}_{4} * \rightarrow \mathrm{CH}_{4}(\mathrm{gas})+*$ & $\mathrm{~K}_{56}$ & $1.01 \times 10^{7}$ & $2.63 \times 10^{7}$ & $6.02 \times 10^{7}$ & $1.27 \times 10^{8}$ \\
\hline & $\Delta \mathrm{E}_{56}=0.22 \mathrm{eV}$ & $\mathrm{k}_{56}^{+}, \mathrm{s}^{-1}$ & $1.94 \times 10^{15}$ & $4.80 \times 10^{15}$ & $1.05 \times 10^{16}$ & $2.13 \times 10^{16}$ \\
\hline \multirow[t]{2}{*}{57} & $\mathrm{CH}_{4} \mathrm{OH}^{*} \rightarrow \mathrm{CH}_{4} \mathrm{OH}($ gas $)+*$ & $\mathrm{~K}_{57}$ & $3.58 \times 10^{3}$ & $3.48 \times 10^{4}$ & $2.47 \times 10^{5}$ & $1.34 \times 10^{6}$ \\
\hline & $\Delta \mathrm{E}_{57}=0.75 \mathrm{eV}$ & $\mathrm{k}_{57}{ }^{+}, \mathrm{s}^{-1}$ & $4.85 \times 10^{11}$ & $4.48 \times 10^{12}$ & $3.04 \times 10^{13}$ & $1.58 \times 10^{14}$ \\
\hline \multirow[t]{2}{*}{58} & $\mathrm{H}_{2} \mathrm{O}^{*} \rightarrow \mathrm{H}_{2} \mathrm{O}$ (gas) $+*$ & $\mathrm{~K}_{57}$ & $4.74 \times 10^{2}$ & $2.82 \times 10^{3}$ & $1.28 \times 10^{4}$ & $4.71 \times 10^{4}$ \\
\hline & $\Delta \mathrm{E}_{58}=0.59 \mathrm{eV}$ & $\mathrm{k}_{57}{ }^{+}, \mathrm{s}^{-1}$ & $8.57 \times 10^{10}$ & $4.84 \times 10^{11}$ & $2.09 \times 10^{12}$ & $7.42 \times 10^{12}$ \\
\hline \multirow[t]{2}{*}{59} & $\mathrm{CO}^{*} \rightarrow \mathrm{CO}(\mathrm{gas})+*$ & $\mathrm{~K}_{58}$ & $3.63 \times 10^{-13}$ & $6.48 \times 10^{-11}$ & $4.88 \times 10^{-9}$ & $1.86 \times 10^{-7}$ \\
\hline & $\Delta \mathrm{E}_{59}=2.05 \mathrm{eV}$ & $\mathrm{k}_{58}{ }^{+}, \mathrm{s}^{-1}$ & $5.26 \times 10^{-5}$ & $8.92 \times 10^{-3}$ & $6.41 \times 10^{-1}$ & $2.34 \times 10^{1}$ \\
\hline \multirow[t]{2}{*}{60} & $0.5 \mathrm{H}_{2}(\mathrm{~g})+* \rightarrow \mathrm{H}^{*}$ & $\mathrm{~K}_{59}$ & $8.24 \times 10^{3}$ & $1.51 \times 10^{3}$ & $3.65 \times 10^{2}$ & $1.10 \times 10^{2}$ \\
\hline & $\Delta \mathrm{E}_{60}=0.65 \mathrm{eV}$ & $\mathrm{k}_{59}{ }^{+}, \mathrm{s}^{-1} \mathrm{bar}^{-1}$ & $7.66 \times 10^{8}$ & $7.28 \times 10^{8}$ & $6.96 \times 10^{8}$ & $6.67 \times 10^{8}$ \\
\hline
\end{tabular}


Figure 1. Reaction network investigated for the hydrodeoxygenation of guaiacol to aromatic products over $\mathrm{Ru}$ (0001). For clarity duplicate structures are highlighted by identical background colors.

Figure 2. Illustration of adsorption sites for guaiacol on the $\mathrm{Ru}(0001)$ surface. There are four possible adsorption sites - atop, bridge, fcc and hcp. At each site, guaiacol has two orientations, $0^{\circ}$ and $30^{\circ}$, referring to the angles of the $\mathrm{C}-\mathrm{C}$ bond to the nearestneighboring $\mathrm{Ru}-\mathrm{Ru}$ bond.

Figure 3. Side (upper panel) and top view (lower panel) of preferred adsorption structure of various intermediates with aromatic rings in the reaction network of the hydrodeoxygenation of guaiacol over Ru (0001).

Figure 4. Side (upper panel) and top view (lower panel) of preferred adsorption structure of various small intermediates in the reaction network of the hydrodeoxygenation of guaiacol over Ru (0001).

Figure 5. Transition state structures of elementary steps 1-24 on the Ru (0001) surface. Upper panels are for side views and lower ones for top views.

Figure 6. Transition state structures of elementary steps $25-51$ on the $\mathrm{Ru}(0001)$ surface. Upper panels are for side views and lower ones for top views. 
Figure 7. Turnover frequencies $\left(\mathrm{s}^{-1}\right)$ of all elementary steps for a reactant pressure of $\mathrm{P}_{\text {guaiacol }}=\mathrm{P}_{\mathrm{H} 2}=1$ bar and a temperature of $573 \mathrm{~K}$. For clarity duplicate structures are highlighted by identical background colors. 
Figure 1
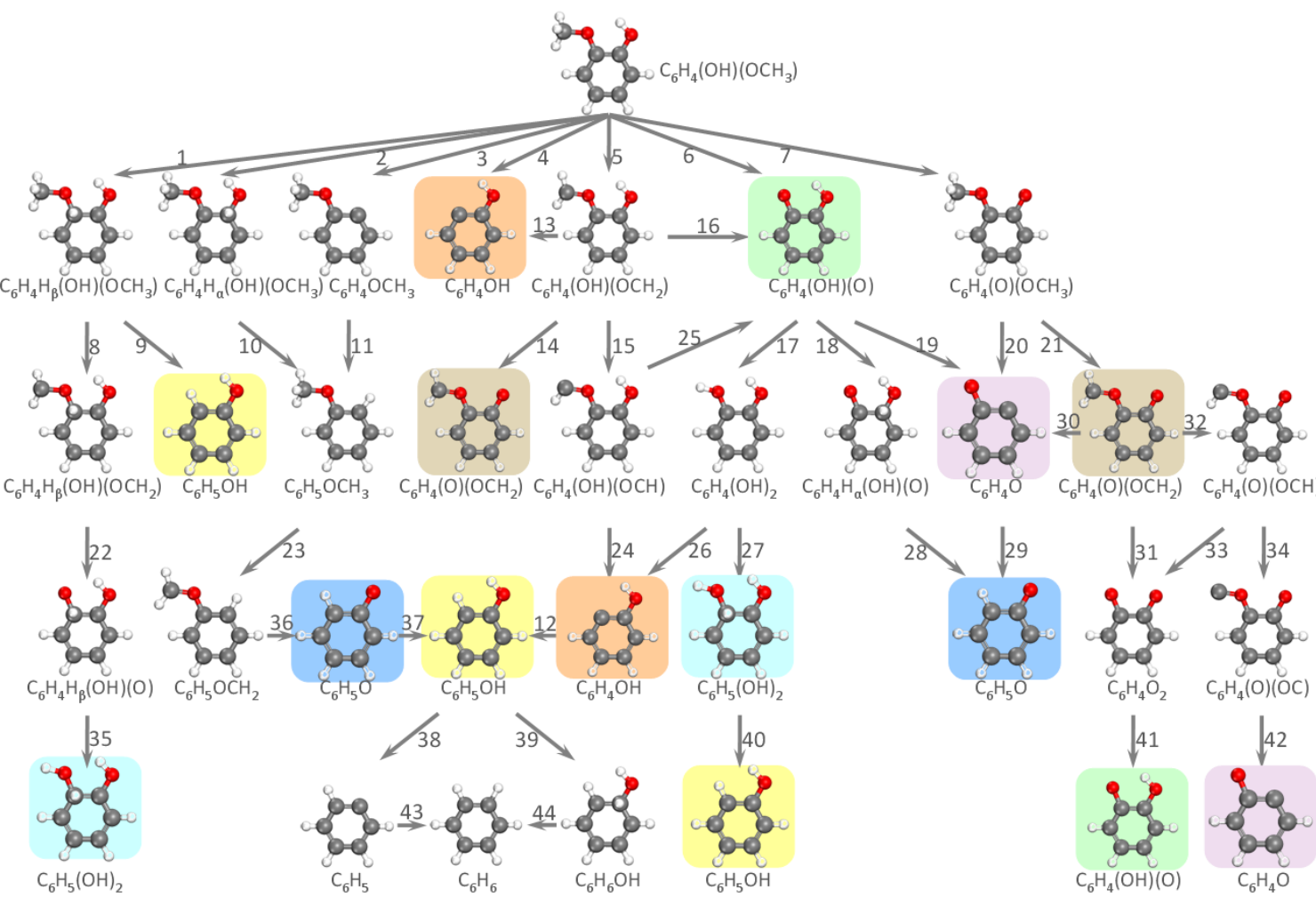
Figure 2

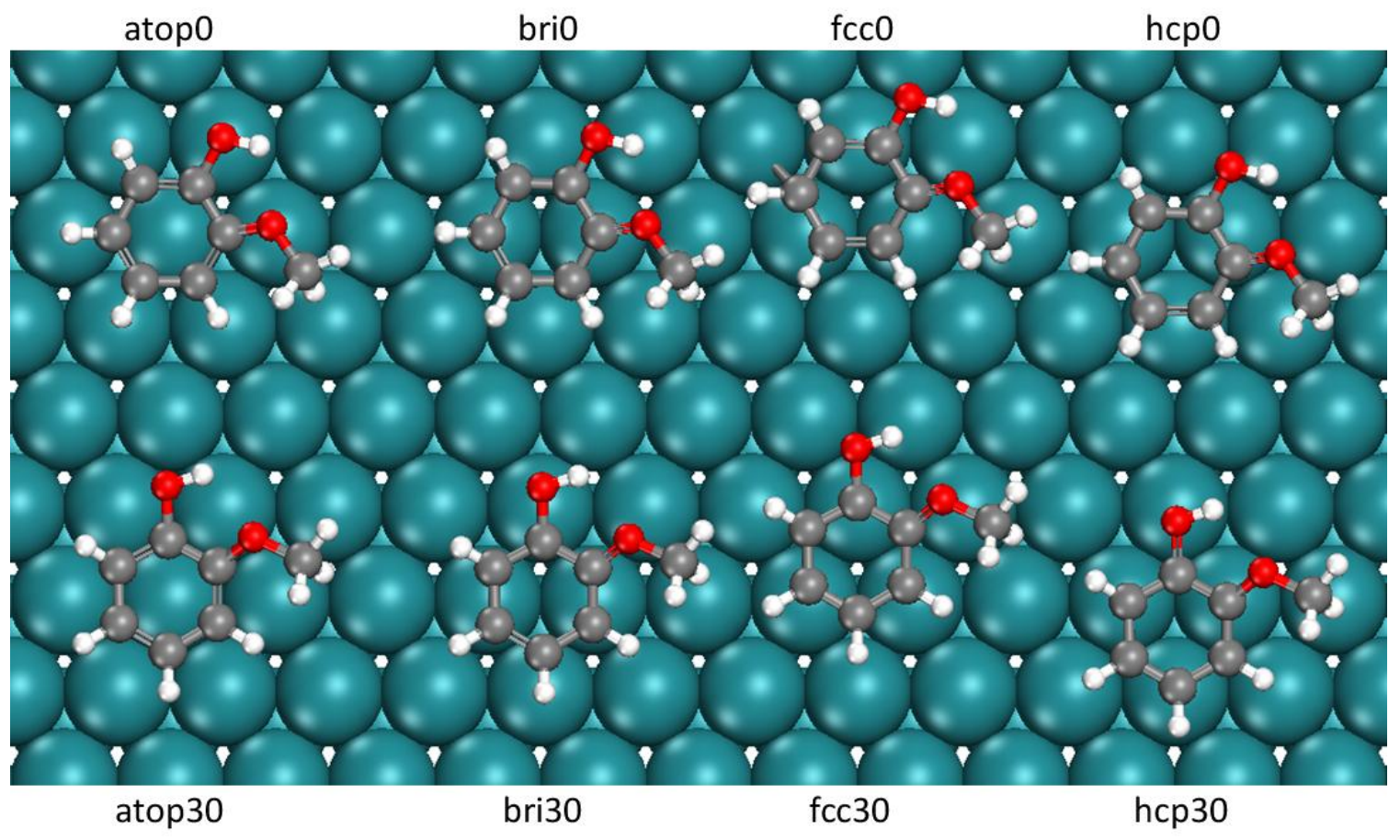


Figure 3
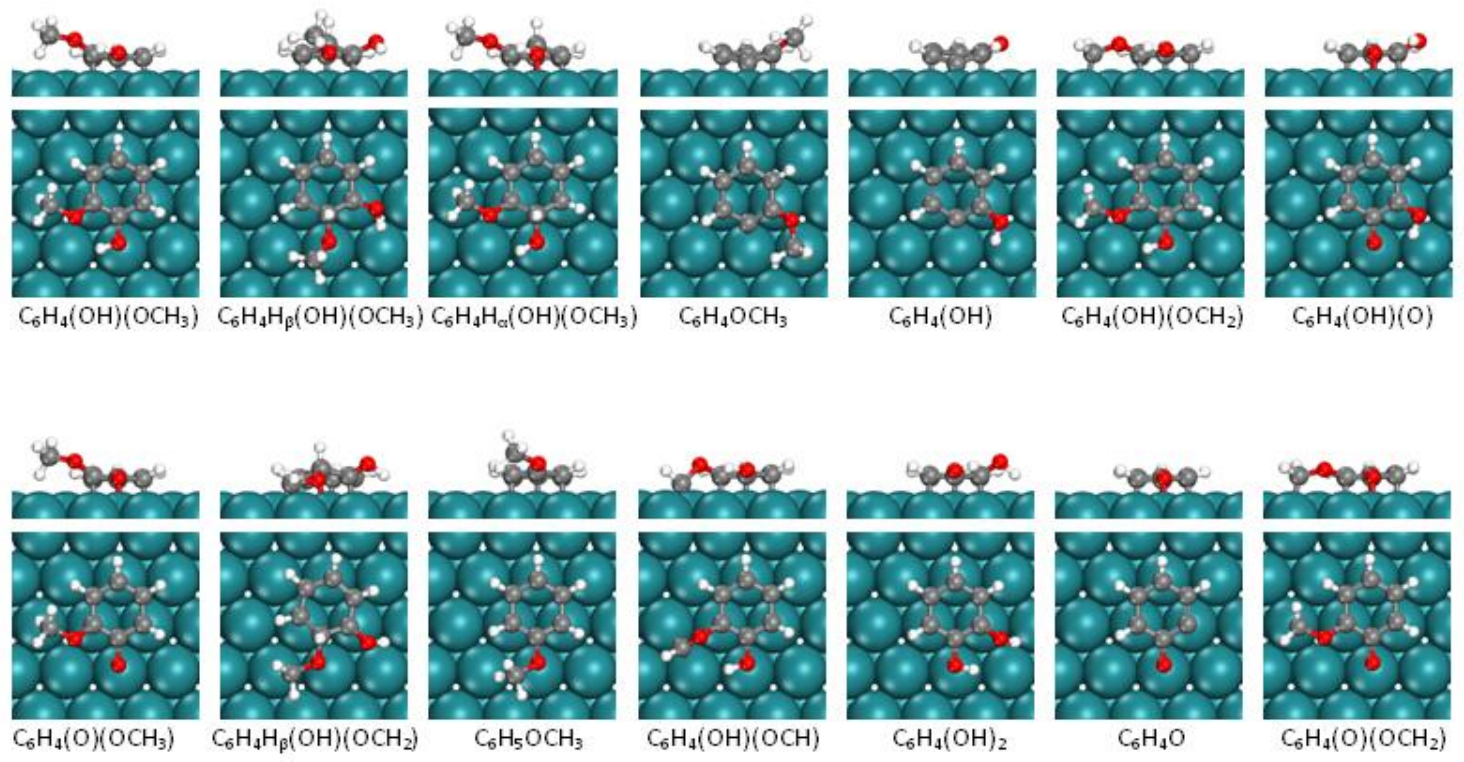

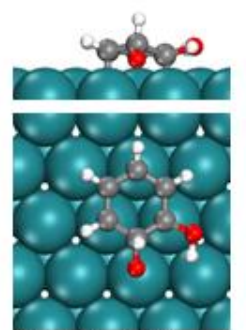

$\mathrm{C}_{6} \mathrm{H}_{4} \mathrm{H}_{\beta}(\mathrm{OH})(\mathrm{O})$

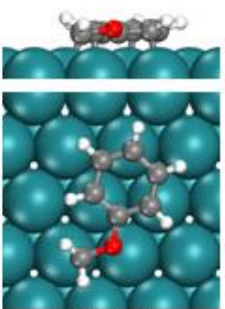

$\mathrm{C}_{6} \mathrm{H}_{5} \mathrm{OCH}_{2}$

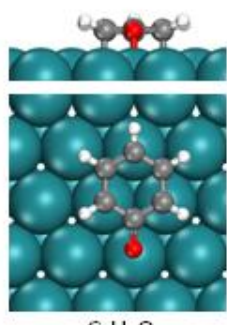

$\mathrm{C}_{6} \mathrm{H}_{5} \mathrm{O}$

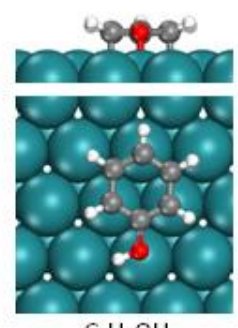

$\mathrm{C}_{6} \mathrm{H}_{5} \mathrm{OH}$

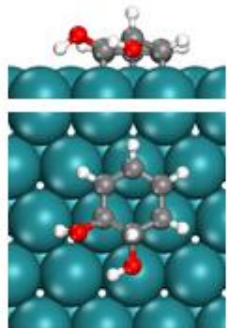

$\mathrm{C}_{6} \mathrm{H}_{5}(\mathrm{OH})_{2}$

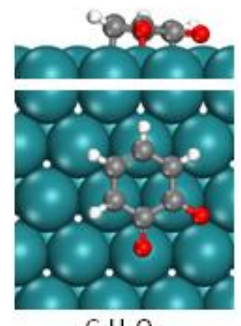

$\mathrm{C}_{6} \mathrm{H}_{4} \mathrm{O}_{2}$

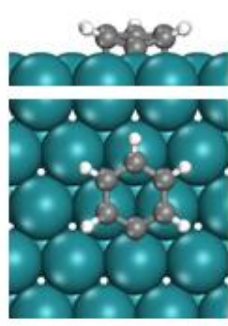

$\mathrm{C}_{6} \mathrm{H}_{5}$

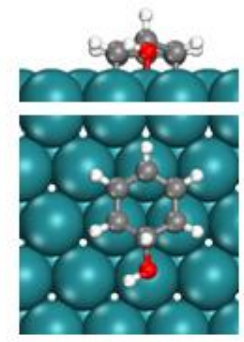

$\mathrm{C}_{6} \mathrm{H}_{6} \mathrm{OH}$

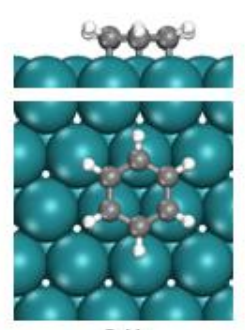

$\mathrm{C}_{6} \mathrm{H}_{6}$

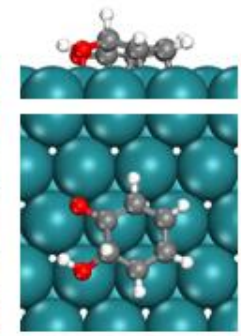

$\mathrm{C}_{6} \mathrm{H}_{4} \mathrm{H}_{a}(\mathrm{OH})(\mathrm{O})$

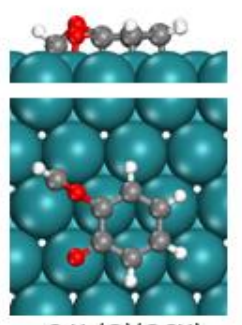

$\mathrm{C}_{6} \mathrm{H}_{4}(\mathrm{O})(\mathrm{OCH})$

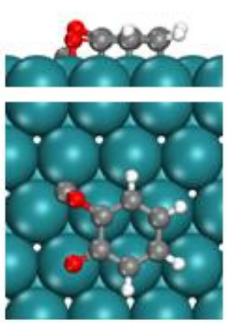

$\mathrm{C}_{6} \mathrm{H}_{4}(\mathrm{O})(\mathrm{OC})$ 
Figure 4
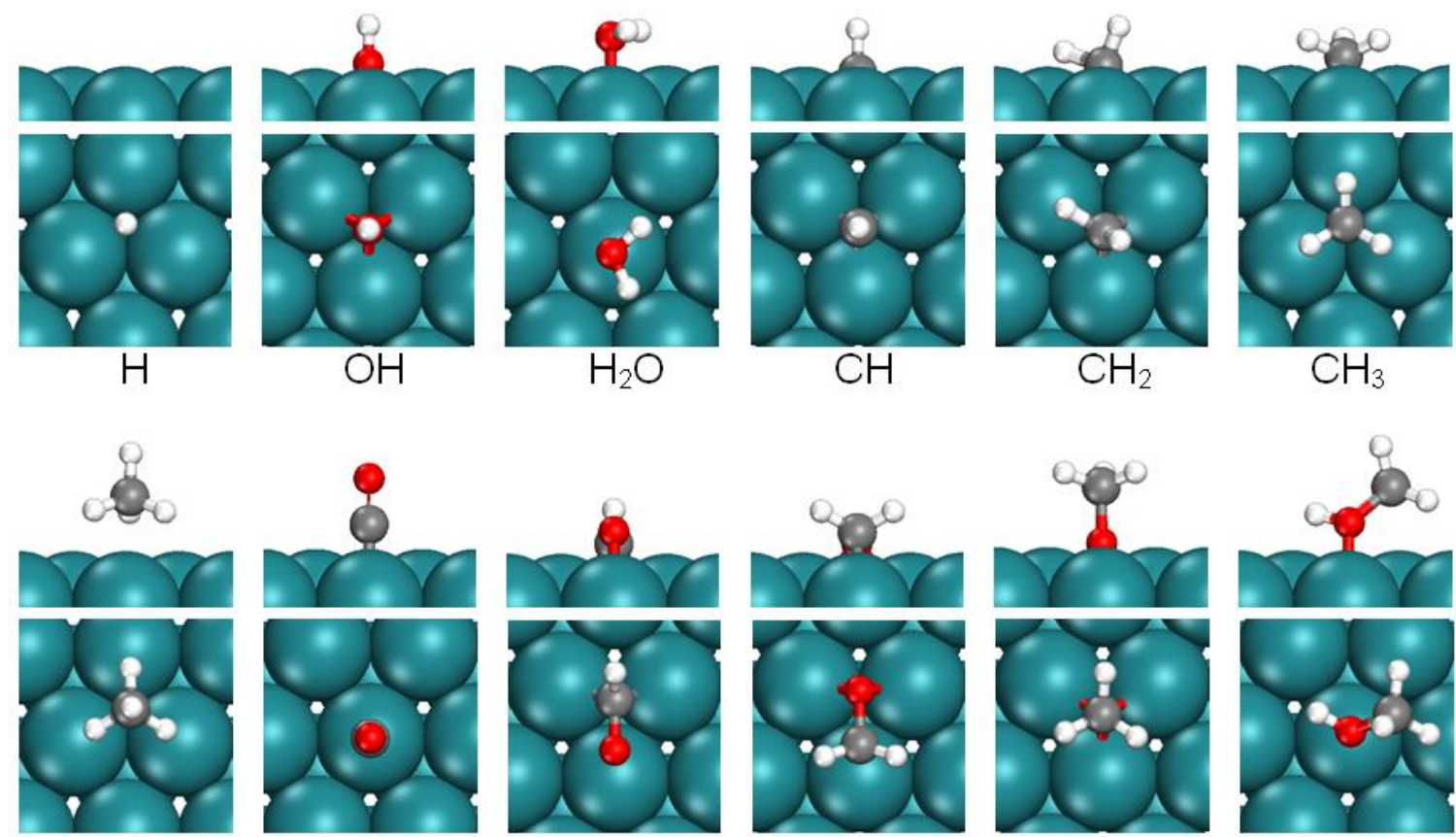

$\mathrm{CH}_{4}$
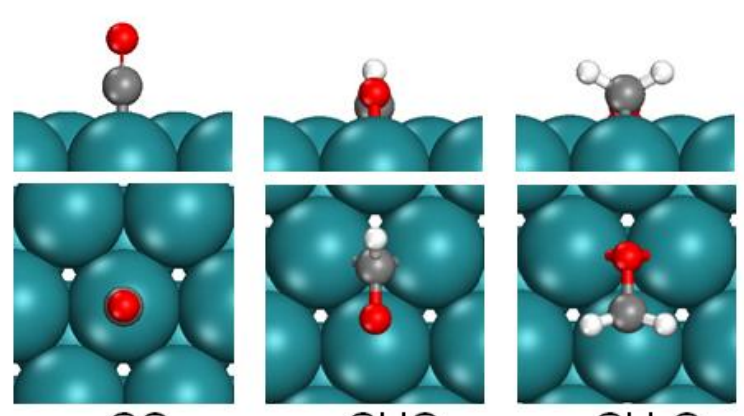

$\mathrm{CH}_{2} \mathrm{O}$

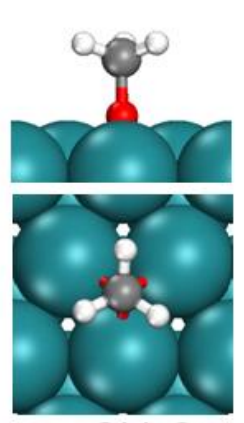

$\mathrm{CH}_{3} \mathrm{O}$

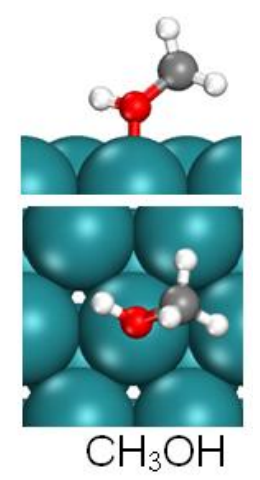


Figure 5

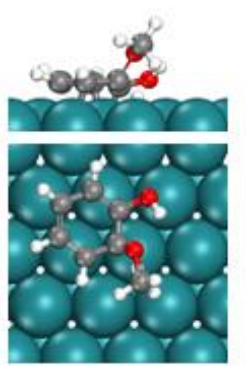

1

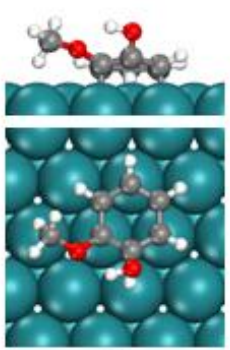

2

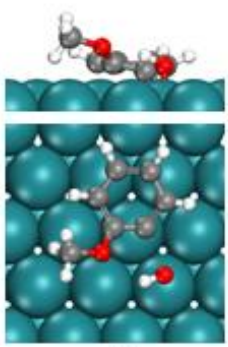

3

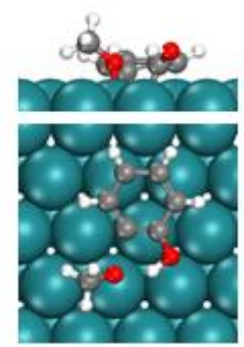

4

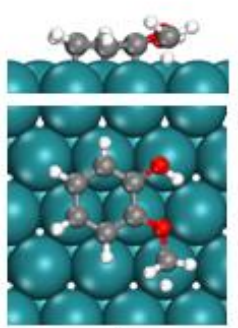

5

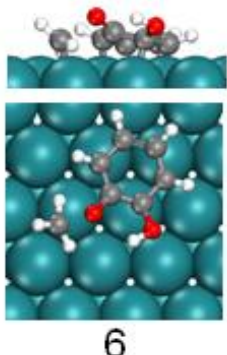

6

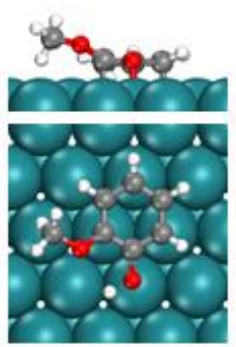

7

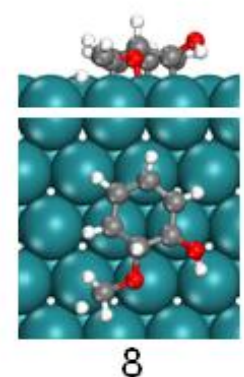

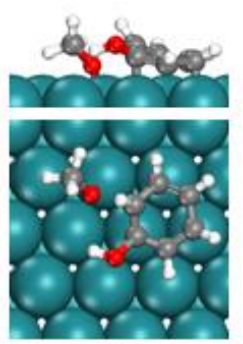

9

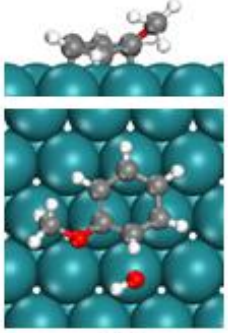

10

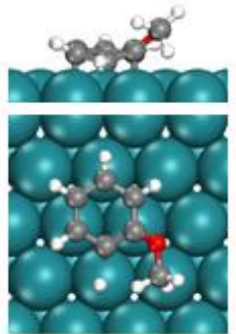

11

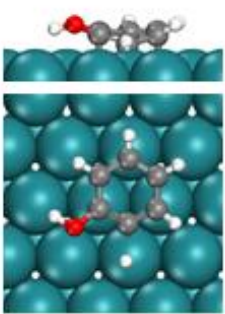

12

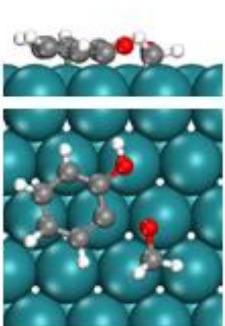

13

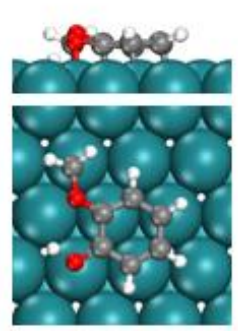

14

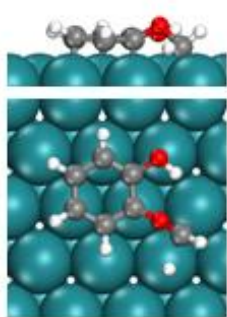

15

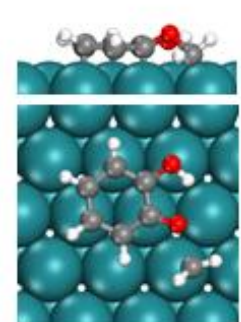

16

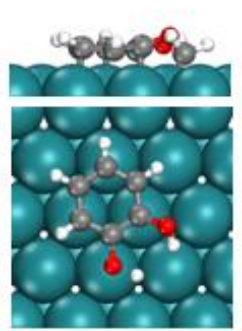

17

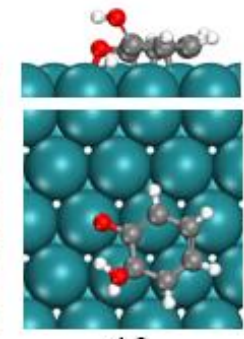

18

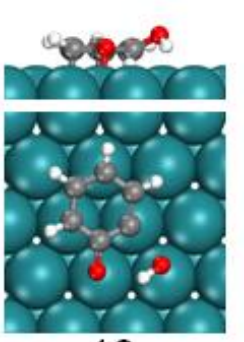

19

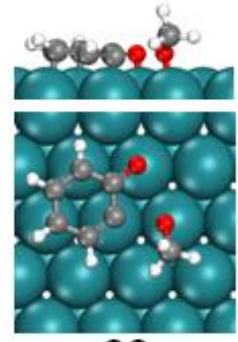

20

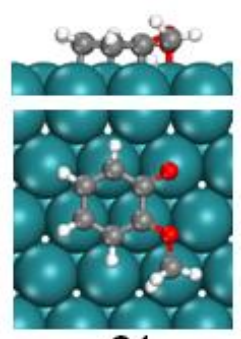

21

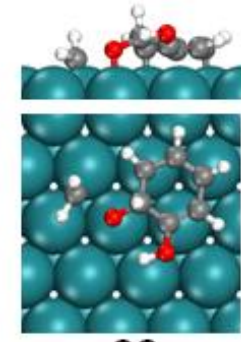

22

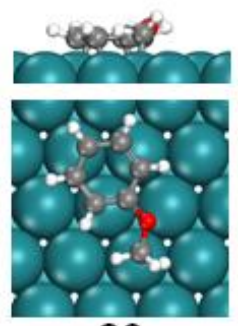

23

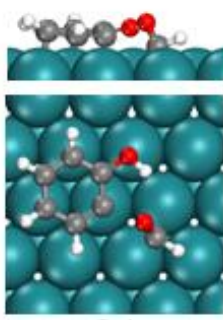

24 
Figure 6
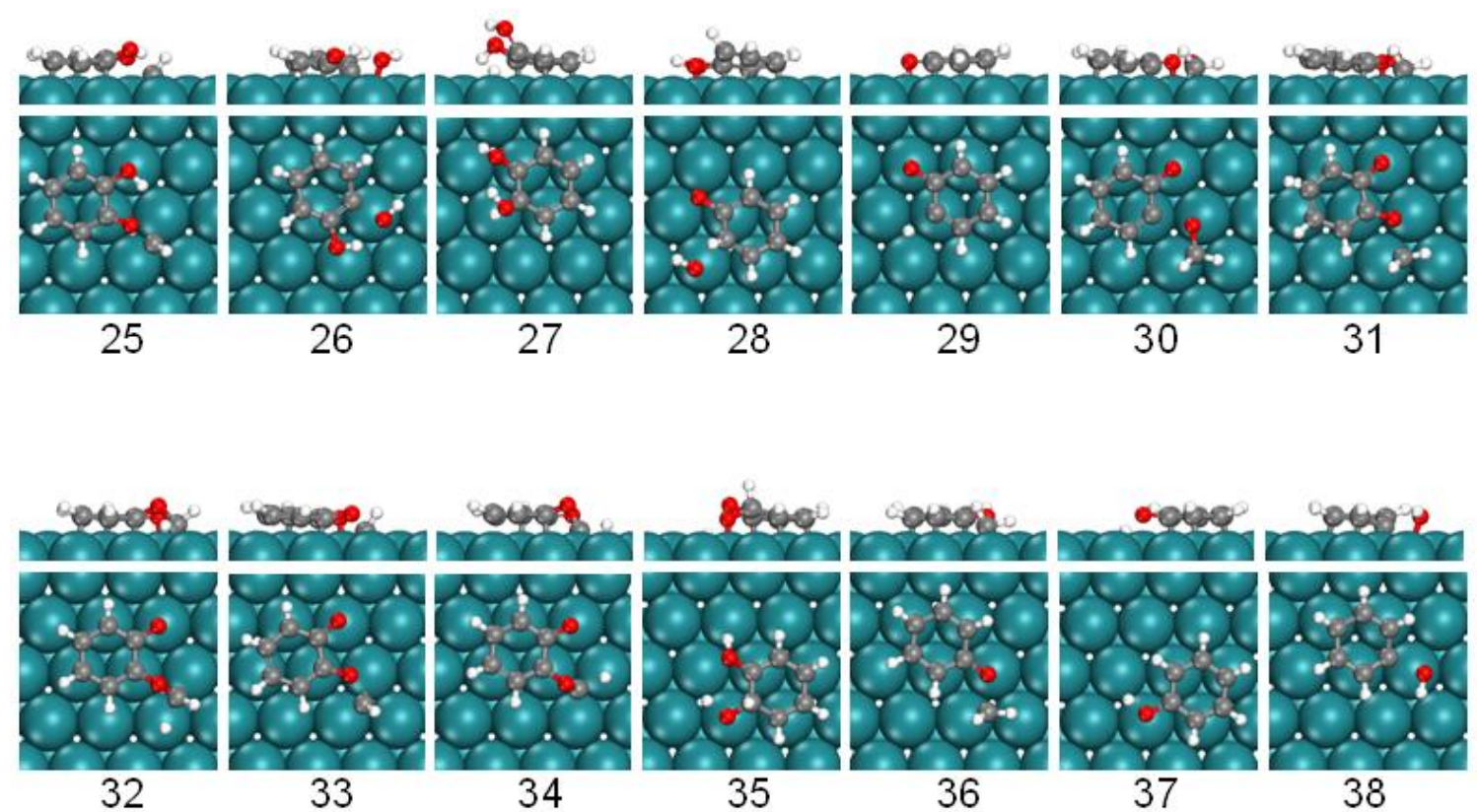

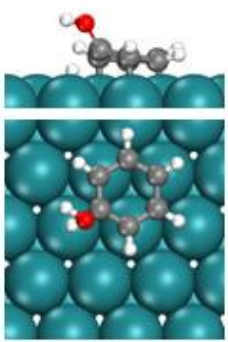

39

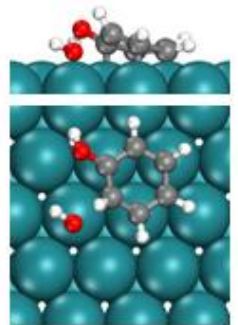

40

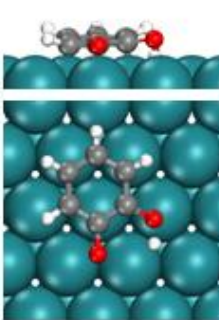

41

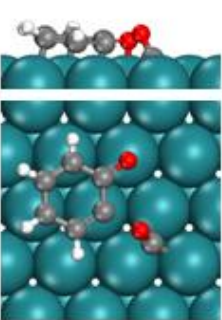

42

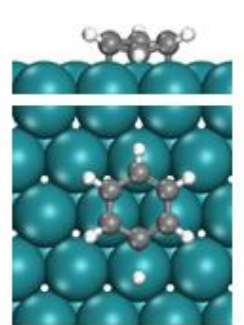

43

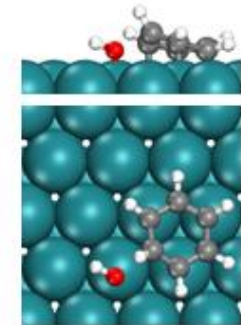

44

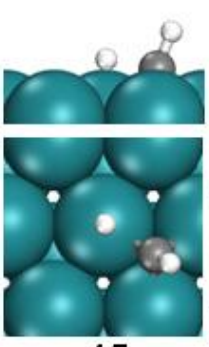

45

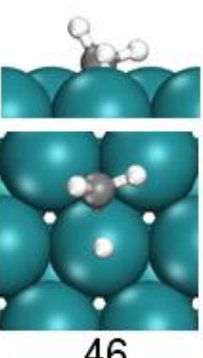

46

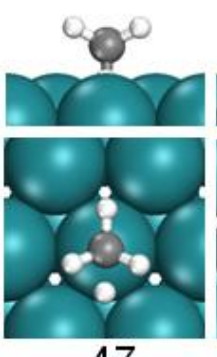

47

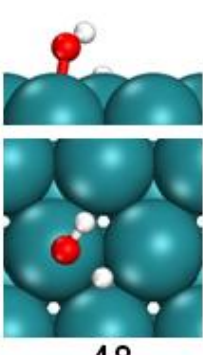

48

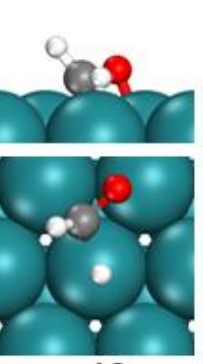

49

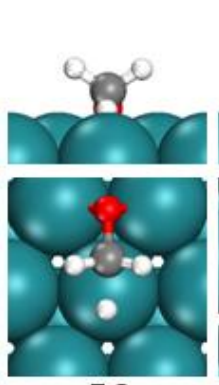

50

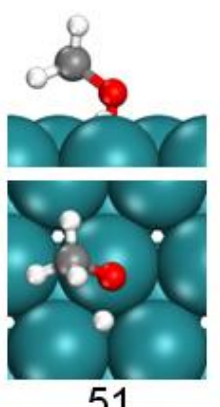


Figure 7

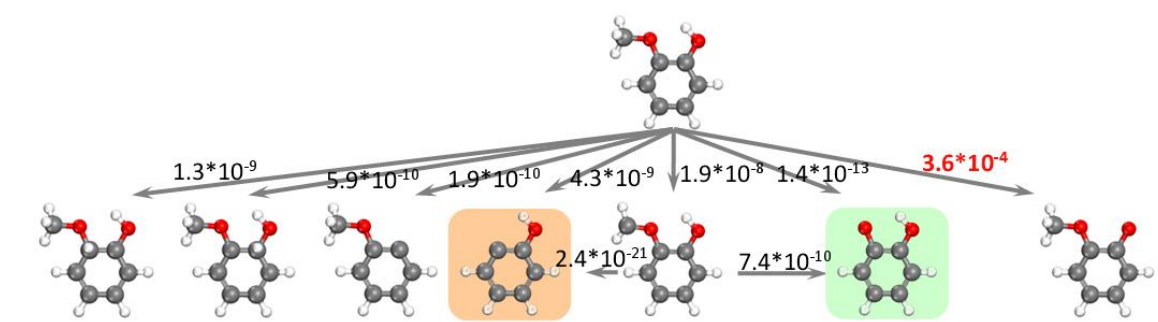

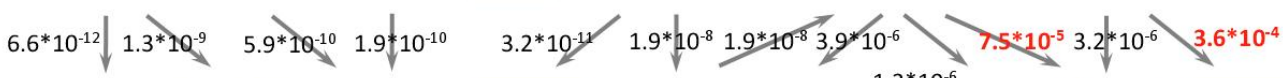

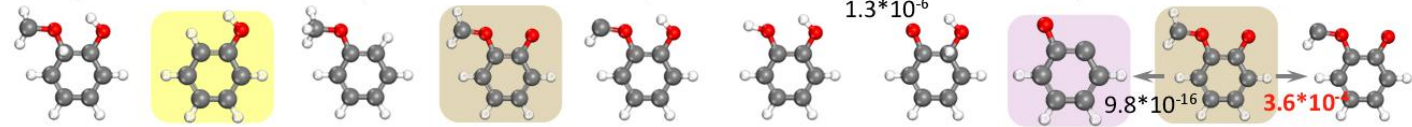

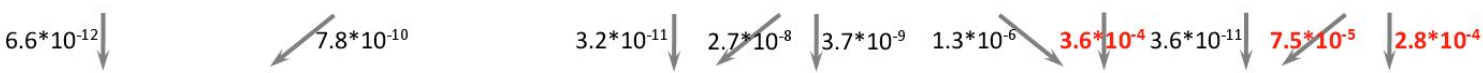
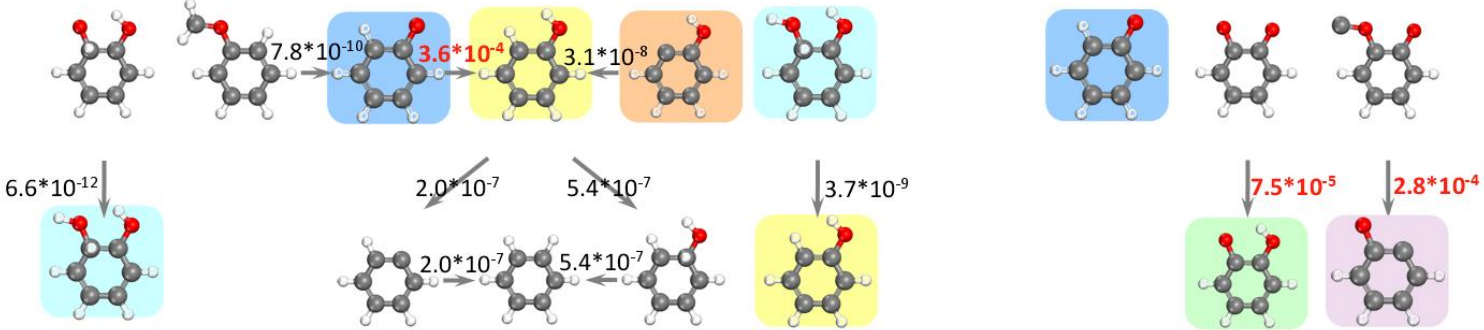


\section{References}

[1] S. Xiu, A. Shahbazi, Renew, Sust. Energy Rev. 16 (2012) 4406-4414.

[2] A. Oasmaa, E. Kuoppala, A. Ardiyanti, R.H. Venderbosch, H.J. Heeres, Energy Fuels 24 (2010) 5264-5272.

[3] T. Sfetsas, C. Michailof, A. Lappas, Q. Li, B. Kneale, J. Chromatogr.A 1218 (2011) 3317-3325.

[4] R.N. Olcese, M. Bettahar, D. Petitjean, B. Malaman, F. Giovanella, A. Dufour, Appl. Catal. B: Environ 115-116 (2012) 63-73.

[5] J.M. Sun, A.M. Karim, H. Zhang, L. Kovarik, X.S. Li, A.J. Hensley, J.-S. McEwen, Y. Wang, J. Catal. 306 (2013) 47-57.

[6] D.C. Elliott, T.R. Hart, Energy Fuels 23 (2009) 631-637.

[7] C. Zhao, J. He, A.A. Lemonidou, X. Li, J.A. Lercher, J. Catal. 280 (2011) 8-16.

[8] A. Gutierrez, R.K. Kaila, M.L. Honkela, R. Slioor, A.O.I. Krause, Catal. Today 147 (2009) 239-246.

[9] Y. Lin, C. Li, H. Wan, H. Lee, C. Liu, Energy Fuels 25 (2011) 890-896.

[10] T. Nimmanwudipong, R.C. Runnebaum, D.E. Block, B.C. Gates, Energy Fuels 25 (2011) 3417-3427.

[11] V.N. Bui, G. Toussaint, D. Laurenti, C. Mirodatos, C. Geantet, Catal. Today 143 (2009) 172-178.

[12] M.A. Gonzalez-Borja, D.E. Resasco, Energy Fuels 25 (2011) 4155-4162.

[13] M.V. Bykova, D.Y. Ermakov, V.V. Kaichev, O.A. Bulavchenko, A.A. Saraev, M.Y. Lebedev, V.A. Yakovlev, Appl. Catal. B: Environ 113-114 (2012) 296-307.

[14] G. Kresse, J. Hafner, Phys. Rev. B 47 (1993) 558-561.

[15] G. Kresse, J. Furthmuller, Comput. Mater. Sci. 6 (1996) 15-50.

[16] G. Kresse, D. Joubert, Phys. Rev. B 59 (1999) 1758-1775.

[17] J.P. Perdew, Y. Wang, Phys. Rev. B 33 (1986) 8800-8802.

[18] J.P. Perdew, Y. Wang, Phys. Rev. B 45 (1992) 13244-13249.

[19] S. Grimme, J. Antony, S. Ehrlich, H. Krieg, J. Chem. Phys. 132 (2010) 154104.

[20] V.A. Finkel, G.P. Kovtun, M.I. Palatnik, Phys. Met. Metallogr. 32 (1971) 231-235.

[21] G. Henkelman, B.P. Uberuaga, H. Jonsson, J. Chem. Phys. 113 (2000) 9901-9904.

[22] G. Henkelman, H. Jonsson, J. Chem. Phys. 111 (1999) 7010-7022.

[23] R.A. Olsen, G.J. Kroes, G. Henkelman, A. Arnaldsson, H. Jonsson, J. Chem. Phys. 121 (2004) 9776-9792.

[24] A. Heyden, A.T. Bell, F.J. Keil, J. Chem. Phys. 123 (2005) 224101.

[25] J.M. Lu, S. Behtash, M. Faheem, A. Heyden, J. Catal. 305 (2013) 56-66.

[26] G. Buzzi-Ferraris, "BzzMath: Numerical libraries in C++", Politecnico di Milano: www.chem.polimi.it/homes/gbuzzi.

[27] A. Antony, C. Hakanoglu, A. Asthagiri, J.F. Weaver, J. Chem. Phys. 136 (2012) 054702.

[28] X.L. Zhou, M.E. Castro, J.M. White, Surf. Sci. 238 (1990) 215-225.

[29] W. Liu, V.G. Ruiz, Z. G.X., B. Santra, X.G. Ren, M. Scheffler, A. Tkatchenko, New J. Phys. 15 (2013) 053046.

[30] O. Dulaurent, M. Nawdali, A. Bourane, D. Bianchi, Appl. Catal. A-Gen. 201 (2000) 271-279.

[31] G. Mercurio, E. McNellis, I. Martin, S. Hagen, F. Leyssner, S. Soubatch, J. Meyer, M. Wolf, P. Tegeder, F. Tautz, Phys. Rev. Lett. 104 (2010) 036102. 
[32] L.C. Grabow, B. Hovlbak, J.K. Norskov, Top. Catal. 53 (2010) 298-310.

[33] C.T. Campbell, Top. Catal. 1 (1994) 353-366.

[34] C.T. Campbell, J. Catal. 204 (2001) 520-524.

[35] C. Stegelmann, A. Andreasen, C. Callaghan, J. Am. Chem. Soc 131 (2009) 80778083. 